\title{
Orchidaceae em um fragmento de Floresta Semidecídua de encosta na região sul do Estado do Espírito Santo, Sudeste do Brasil
}

\author{
Amauri Herbert Krahl ${ }^{1,4}$, Antônio Jesus Dorighetto Cogo ${ }^{2}$ e Jefferson José Valsko ${ }^{3}$
}

Recebido: 7.05.2013; aceito: 9.01.2014

\begin{abstract}
Orchidaceae in a fragment of semideciduous slope forest in the southern Espírito Santo State, Southeastern Brazil). The present study aimed to inventory and elaborate descriptions and illustrations for the species of Orchidaceae found in a forest located in the southern Espírito Santo State, a region of few botanical studies, featuring a poorly known flora. During the study, 25 species were found and distributed into 21 genera. The majority of the species were epiphytic, represented by 16 species, followed by rupiculous, terrestrial, and mycoheterotrofic species. Most species flourished during the hot and humid period. Furthermore, the study revealed the presence of an endemic species and three new records for the State.
\end{abstract}

Keywords: Atlantic Forest, conservation, orchids, taxonomy

RESUMO - (Orchidaceae em um fragmento de Floresta Semidecídua de encosta na região sul do Estado do Espírito Santo, Sudeste do Brasil). O presente trabalho teve como objetivo inventariar e elaborar descrições e ilustrações para as espécies de Orchidaceae encontradas em um fragmento de Floresta Semidecídua localizado no sul do Estado do Espírito Santo, região de poucos estudos, caracterizando uma flora ainda pouco conhecida. Durante o estudo, 25 espécies distribuídas em 21 gêneros, foram registradas. A forma de vida predominante foi a epifítica, caracterizada por 16 espécies, seguida pela rupícola, terrícola e micoheterotrófica. A maior parte das espécies floresceu no período quente e úmido. Além disso, o estudo revelou a presença de uma espécie endêmica e três novas ocorrências para o Estado.

Palavras-chave: Conservação, Mata Atlântica, orquídeas, taxonomia

\section{Introdução}

A Mata Atlântica é considerada um dos principais hotspots mundiais por apresentar elevado número de espécies, alto grau de endemismo e ser ameaçada, devido à rápida redução de sua cobertura original, que ultrapassa $70 \%$ de desmatamento (Myers et al. 2000). Em decorrência da alta fragmentação que o bioma vem sofrendo, é inevitável o desequilíbrio na manutenção de fatores que determinam a dinâmica conhecida dos sistemas biológicos, pondo em risco diversos ecossistemas (Rodrigues \& Nascimento 2006). No Estado do Espírito Santo todas as diferentes fisionomias da Mata Atlântica ocupavam aproximadamente $90 \%$ do território, o restante era ocupado por rios, lagos e afloramentos rochosos, porém com o decorrer dos anos houve rápida redução desta cobertura e atualmente restam cerca de $30 \%$ da cobertura original (Assis 2007).

Dentre as diferentes tipologias da Mata Atlântica no ES, pode-se destacar as Florestas Estacionais Semideíduas, que representam a segunda mais importante formação vegetacional em termos de área ocupada, com cerca de $23 \%$ do território capixaba, localizada principalmente na porção sul do Estado (Assis et al. 2007). Essa formação se caracteriza pela deficiência hídrica e/ou queda da temperatura nos meses mais frios e secos do ano, fato este que promove a queda parcial das folhas $(20 \%$ a $50 \%$ de deciduidade) nos indivíduos arbóreos dominantes (Veloso et al. 1991). Mesmo constituindo a segunda formação vegetacional mais importante em terras

1. Instituto Nacional de Pesquisas da Amazônia, Programa de Pós-Graduação em Botânica, Departamento de Botânica, Avenida André Araújo, 2936, 69.060-001 Manaus, AM, Brasil

2. Universidade Estadual Norte Fluminense, Departamento de Biociências e Biotecnologia, Avenida Alberto Lamego, 28.000-000 Campos dos Goytacazes, RJ, Brasil

3. Universidade Federal do Amazonas, Programa de Pós-Graduação em Diversidade Biológica, Avenida General Rodrigo Otávio Jordão Ramos 3000, 69.077-000 Manaus, AM, Brasil

4. Autor para correspondência: amaurikrahl@hotmail.com 
capixabas, ainda pouco se sabe sobre ela, devido à escassez de estudos (Assis et al. 2007).

Orchidaceae abrange cerca de $7 \%$ das plantas epífitas e corresponde a um dos maiores grupos botânicos com aproximadamente de 24.500 espécies distribuídas em 800 gêneros (Dressler 2005, Fay \& Chase 2009), com a maior riqueza nas regiões tropicais (Atwood 1986). Recentemente Barros et al. (2010) apresentaram uma lista das espécies brasileiras de Orchidaceae atualizando para 2.419 espécies subordinadas a 235 gêneros. Para a região Sudeste do Brasil, vários estudos têm sido desenvolvidos nos últimos anos, os quais estão contribuindo para o enriquecimento do conhecimento da família (e.g. Menini-Neto et al. 2004a, b, MeniniNeto et al. 2007, Pansarin \& Pansarin 2008, Abreu \& Menini-Neto 2010, Ferreira et al. 2010, Abreu et al. 2011). Estudos para esta família no Estado do Espírito Santo são escassos e realizados, em sua maioria, para as restingas (e.g. Fraga \& Pereira 1998, Fraga \& Peixoto 2004, Rodrigues \& Simonelli 2007, Krahl et al. 2010), sendo raros no interior (e.g. Pereira \& Ribeiro 2004). Uma obra sobre a família no Estado foi realizada por Ruschi (1986), a qual agrupou uma série de informações sobre as orquídeas encontradas, contudo necessita de atualizações, pois desde sua publicação, muitas outras novas informações surgiram. Recentemente Chiron (2013) e Chiron \& Bolsanello (2013) apresentaram uma série de informações referentes a diversas espécies ocorrentes no Estado do Espírito Santo, mais especificamente para a Serra do Castelo.

Devido à perda acelerada de hábitats e à carência de informações sobre Orchidaceae nas Florestas Estacionais Semidecíduas da porção sul do Estado do Espírito Santo, este trabalho se justifica pela necessidade do levantamento de informações sobre as espécies botânicas encontradas nessas regiões de grande importância ecológica, utilizadas como refúgio da vida selvagem e banco genético de várias espécies da flora e fauna, mas que, infelizmente, são pouco conhecidas. Por este motivo, o trabalho teve como objetivo inventariar e descrever as espécies de Orchidaceae ocorrentes em um fragmento de Florestal Estacional Semidecídua de encosta no município de Cachoeiro de Itapemirim, visando prover informações ecológicas sobre a riqueza e as formas de vida predominantes dessa família nesses ambientes.

\section{Material e métodos}

O fragmento florestal estudado localiza-se na encosta de um afloramento rochoso granítico conhecido como Pedra do Fio, na comunidade de Barra Alegre, zona rural do distrito de Burarama, município de Cachoeiro de Itapemirim (ES), na divisa com o município de Castelo (ES), com coordenadas centrais $20^{\circ} 37^{\prime} \mathrm{S}$ e $41^{\circ} 19^{\prime} \mathrm{W}$ (dados obtidos por GPS). A área possui uma extensão territorial de aproximadamente 25 ha, sendo atravessado em toda sua extensão por um curso d'água. A altitude varia de 400 até $680 \mathrm{~m}$, característica de uma região de transição entre Floresta Estacional Semidecídua Submontana (50-500 m) para Montana (500-1.500 m) (Veloso et al. 1991). A vegetação é caracterizada por apresentar dossel alto, com exemplares arbóreos de 15 a $20 \mathrm{~m}$ de altura aproximadamente, com a presença de indivíduos emergentes, estrato arbustivo-herbáceo bem desenvolvido, grande quantidade de palmeiras e um número considerável de epífitas, principalmente, em árvores ao longo do riacho.

O estudo foi realizado entre abril de 2008 e março de 2009, com excursões mensais utilizando o método de caminhamento (Filgueiras et al. 1994), procurando abranger toda a extensão territorial da área à procura de material botânico, durante as quais foram coligidas informações e anotações adicionais sobre cada táxon. Espécimes férteis foram coletados e herborizados conforme Mori et al. (1989) e incorporados ao acervo do herbário VIES da Universidade Federal do Espírito Santo. Algumas inflorescências foram conservadas em álcool a 70\% para análise taxonômica e para confecção das ilustrações.

As espécies foram identificadas por meio de consultas às obras de Rodrigues (1877, 1882), Cogniaux (1893-1896, 1898-1902, 1904-1906), Hoehne (1940, 1942, 1945, 1949, 1953), Pabst \& Dungs (1975, 1977) e Sprunger et al. (1996), além das descrições originais dos táxons, e consulta a especialistas e aos acervos dos herbários CVRD, MBML e VIES (acrônimos de acordo com Thiers 2013). A nomenclatura seguiu a lista de espécies da Flora do Brasil (Barros et al. 2013). Os dados de floração e hábitat foram obtidos por meio de observações em campo e a distribuição geral de cada táxon foi obtida também na Lista de Espécies da Flora do Brasil (Barros et al. 2013).

\section{Resultados e Discussão}

Um total de 26 espécies foi encontrado na área de estudo: Acianthera capillaris (Lindl.) Pridgeon \& M.W. Chase, Acianthera nemorosa (Barb. Rodr.) F. Barros, Aspidogyne argentea (Vell.) Garay, 
Aspidogyne mendoncae (Brade \& Pabst) Ormerod, Brasiliorchis consanguinea (Klotzsch) R. Singer, S. Koehler \& Carnevali, Christensonella pumila (Hook.) Szlach., Mytnik, Górniak \& Smiszek., Cirrhaea dependens Loudon, Eltroplectris janeirensis (Porto \& Brade) Pabst, Eltroplectris triloba (Lind.) Pabst, Epidendrum avicula Lindl., Epidendrum hololeucum Barb. Rodr., Grandiphyllum auricula (Vell.) Docha Neto, Lockhartia lunifera Rchb. f., Mormolyca rufescens (Lind1.) M.A. Blanco, Octomeria juncifolia Barb. Rodr., Octomeria tricolor Rchb. f., Oeceoclades maculata (Lindl.) Lindl., Pabstiella hians (Lindl.) Luer, Pabstiella trifida (Lindl.) Luer, Polystachya sp., Prescottia plantaginifolia Lindl. ex Hook., Specklinia marginalis (Rchb. f.) F. Barros, Stanhopea guttulata Lindl., Stelis papaquerensis Rchb. f., Wullschlaegelia aphylla (Sw.) Rchb. f., e Xylobium variegatum (Ruiz \& Pav.) Garay \& Dunst. Dentre os 21 gêneros encontrados, aqueles com maior riqueza foram Aspidogyne, Eltroplectris, Epidendrum, Octomeria e Pabstiella com duas espécies cada. Comparando com trabalhos realizados em áreas de Florestas Estacionais Semidecíduas ou decíduas (Menini Neto 2004a, b, Menini Neto et al. 2007, Pansarin \& Pansarin 2008, Rodriguez et al. 2009, Ferreira et al. 2010, Bastos \& van den Berg 2012), no presente estudo foi encontrado um número expressivo de espécies levando-se em consideração o tempo de coleta realizado. O mesmo acontece quando os dados são comparados com os das restingas do Estado do Espírito Santo (Fraga \& Peixoto 2004, Rodrigues \& Simonelli 2007). Nestes trabalhos observa-se a predominância de espécies pertencentes à subtribo Pleurothalidiinae (Menini Neto 2004a, Menini Neto et al. 2007, Pansarin \& Pansarin 2008, Ferreira et al. 2010, Bastos \& van den Berg 2012) como observado para o presente estudo.

Quanto à forma de vida, foram encontradas 16 espécies epífitas, seis terrícolas, quatro rupícolas e uma micoheterotrófica, podendo estas apresentar mais de um hábito de vida. Diversos outros trabalhos para Orchidaceae desenvolvidos em formações da Mata Atlântica demonstram a predominância do hábito epifítico, por exemplo, nas Florestas Ombrófilas dos Estados do Rio de Janeiro (Miller \& Warren 1994, Cunha \& Forzza 2007) e Minas Gerais (Menini Neto et al. 2007). O mesmo é observado também para as Florestas Estacionais Semidecíduas de Minas Gerais (Menini Neto et al. 2004a, b), São Paulo (Pansarin \& Pansarin 2008) e Rio Grande do Sul (Buzatto et al. 2007), e para as restingas do Estado do Espírito Santo (Fraga \& Peixoto 2004, Rodrigues \& Simonelli 2007).
Em relação à época de floração, a maioria das espécies foi observada florida nos meses de janeiro a março, e uma pequena parte nos meses de maio a julho, períodos que coincidem, respectivamente, com a época quente/úmida e fria/seca. Resultados similares de floração já foram apresentados por outros autores, como por exemplo, por Batista et al. (2005) na Reserva Ecológica do Guará no Distrito Federal, por Pansarin \& Pansarin (2008) para a Serra do Japi em São Paulo e por Ferreira et al. (2010) para fragmentos florestais na região central de São Paulo.

Todas as espécies encontradas possuem ocorrência para o Sudeste brasileiro, $65 \%$ ocorrem na região Sul, $50 \%$ no Nordeste, $30,77 \%$ no Norte e $23,08 \%$ no Centro-Oeste (Barros et al. 2013). Diferentes padrões de distribuição são observados, tais como, a distribuição ampla pelo território nacional e distribuição restrita. $\mathrm{Na}$ distribuição ampla enquadram-se espécies que se distribuem de forma contínua, tais como L. lunifera, M. rufescens, O. maculata e W. aphylla, e aquelas que se distribuem de forma disjunta, principalmente ente a Amazônia e a Mata Atlântica, como por exemplo, C. pumila, S. marginalis, S. papaquerensis e $X$. variegatum. Esta disjunção se dá pela ocorrência de um corredor seco entre estes dois biomas, sendo que estas espécies são típicas de ambientes com níveis elevados de umidade atmosférica, como observado para a Mata Atlântica e Amazônia. Com o padrão restrito observam-se espécies ocorrendo na região Leste do Brasil, que podem ocorrer do Nordeste até o Sul do Brasil, como por exemplo, A. capillaris, A. nemorosa, A argentea, A. mendoncae, $B$. consanguinea, C. dependens, E. janeirensis, E. triloba, E. hololeucum, G. auricula, O. juncifolia, P. hians, P. plantaginifolia e $S$. guttulata. Destas, algumas estão restritas somente à região Sudeste, tais como, A. mendoncae, B. consanguinea, E. janeirensis, E. hololeucum, G. auricula, S. guttulata. Algumas apresentam também disjunção na sua distribuição, como visto para E. avicula, O. tricolor e P. trifida. Além disso, no presente estudo foram identificadas cinco novas ocorrências para o Estado: Eltroplectris janeirensis, Specklinia marginalis, Stanhopea guttulata, Stelis papaquerensis e Wullschlaegelia aphylla, além de uma espécie endêmica do Estado do Espírito Santo, Aspidogyne mendoncae. Estas descobertas justificam a importância dos trabalhos taxonômicos e florísticos para o Estado do Espírito Santo, principalmente em regiões carentes em trabalhos técnico-científicos, como a porção sul do Estado. 
Chave para a identificação das espécies

1. Plantas terrícolas ou micoheterotróficas

2. Plantas áfilas

2.Plantas foliadas

3. Caule intumescido em pseudobulbo

25. Wullschlaegelia aphylla

3. Caule não intumescido em pseudobulbo

4. Flores sem cálcar

17. Oeceoclades maculata

4. Flores com cálcar

5. Sépalas pilosas externamente

4. Aspidogyne mendoncae

5. Sépalas totalmente glabras

3. Aspidogyne argentea

6. Lâmina foliar com nervuras esbranquiçadas e reticuladas

6. Lâmina foliar com nervuras verde-claras e paralelas

7. Inflorescência com mais de $60 \mathrm{~cm}$ de comprimento; pecíolo profundamente canaliculado;

lâmina foliar ovada; flores creme

8. Eltroplectris janeirensis

7. Inflorescência com menos de $60 \mathrm{~cm}$ de comprimento; pecíolo sem canalículo ou levemente canaliculado; lâmina foliar lanceolada; flores esverdeadas .

1. Plantas epífitas ou rupícolas

8. Caule intumescido em pseudobulbo

9. Plantas com folhas portando bainha foliar amplexicaule

20. Polystachya sp.

9. Plantas com folhas emergindo do ápice do pseudobulbo

10. Disco do labelo sem calo

23. Stanhopea guttulata

10. Disco do labelo com algum tipo de calo

11. Sépalas pilosas externamente

10. Epidendrum avicula

11. Sépalas totalmente glabras

12. Pseudobulbos unifoliados

13. Folhas com menos de $5 \mathrm{~cm}$ de comprimento

6. Christensonella pumila

13. Folhas com mais de $5 \mathrm{~cm}$ de comprimento

14. Folhas plicadas

7. Cirrhaea dependens

14. Folhas conduplicadas

15. Inflorescência multiflora; labelo bilobado; disco com cinco calos digitiformes

12. Grandiphyllum auricula

15. Inflorescência uniflora; labelo trilobado; disco com um calo longitudinal

14. Mormolyca rufescens

12. Pseudobulbos bifoliados

16. Inflorescência multiflora

26. Xylobium variegatum

16. Inflorescência uniflora

5. Brasiliorchis consanguinea

8. Caule não intumescido em pseudobulbo

17. Sépalas laterais coalescentes lateralmente em mais da metade do comprimento ou todas as sépalas coalescentes basalmente

18. Inflorescência com mais de 20 flores

24. Stelis papaquerensis

18. Inflorescência com menos de 20 flores

19. Pétalas com margem fimbriada

2. Acianthera nemorosa

19. Pétalas com margem inteira

20. Labelo trilobado

1. Acianthera capillaris

20. Labelo oblongo ou triangular a lanceolado

21. Cauloma com mais de $2,5 \mathrm{~cm}$ de comprimento; folha com mais de $6 \mathrm{~cm}$ de comprimento 18. Pabstiella hians

21. Cauloma com menos de $2,5 \mathrm{~cm}$ de comprimento; folha com menos de $6 \mathrm{~cm}$ de comprimento 
22. Inflorescência com mais de 5 flores; flores alvas a creme-esverdeadas

22. Specklinia marginalis

22. Flores com menos de 3 flores; flores amarelas com listras acastanhadas

19. Pabstiella trifida

17. Sépalas livres ou as laterais ligeiramente coalescentes pela base

23. Cauloma unifoliado

24. Folha cilíndrica

24. Folha plana

15. Octomeria juncifolia

16. Octomeria tricolor

23. Caule multifoliado

25. Labelo inteiro; folhas concentradas na porção distal do caule

11. Epidendrum hololeucum

25. Labelo 5-lobado; folhas recobrindo todo o caule

13. Lockhartia lunifera

1. Acianthera capillaris (Lindl.) Pridgeon \& M.W. Chase, Lindleyana 16(4): 242. 2001.

Figuras 1 a, 5 a

Planta epífita. Rizoma inconspícuo. Caule não intumescido em pseudobulbo, do tipo cauloma. Cauloma 4,4-6,7 cm compr., cilíndrico, unifoliado; bainhas do cauloma ca. 1,9 cm compr., tubulares, amplexicaules, ápice agudo. Folha 4,4-4,6×0,5-0,6 cm, estreitamente elíptica, verde, ápice agudo. Inflorescência ca. 3,6 cm compr., em racemo, levemente encurvada, 4-5-flora; pedúnculo ca. 1,8 cm compr., ereto; bainhas do pedúnculo não observadas; brácteas florais ca. $0,2 \times 0,1 \mathrm{~cm}$, lanceoladas, amplectivas, ápice agudo. Flores de coloração creme-amarelado; sépala dorsal ca. $0,4 \times 0,1 \mathrm{~cm}$, elíptica, ápice agudo; sépalas laterais ca. $0,4 \times 0,1 \mathrm{~cm}$, coalescentes lateralmente até a proximidade do ápice formando um sinsépalo, ápice agudo; sinsépalo ca. $0,4 \times 0,2 \mathrm{~cm}$; pétalas ca. $0,3 \times 0,1 \mathrm{~cm}$, elípticas, ápice agudo, assimétricas, levemente encurvadas; labelo ca. $0,25 \times 0,1 \mathrm{~cm}$, trilobado; lobos laterais ca. 0,03 $\times 0,02 \mathrm{~cm}$, dentiformes, ápice agudo; lobo terminal ca. $0,1 \times 0,05 \mathrm{~cm}$, lanceolado, ápice agudo; coluna ca. $0,15 \mathrm{~cm}$ compr., alva; polínias não observadas. Fruto não observado.

Material examinado: BRASIL: Espírito SANTo: Cachoeiro de Itapemirim, Distrito de Burarama, Barra Alegre, 20-IV-2008, floresceu em cultivo em 19-X-2010, A.H. Krahl s.n. (VIES26234).

Acianthera capillaris se distribui pelos Estados da BA, ES, MG e SP (Barros et al. 2013). Na área de estudo a espécie foi encontrada estéril e floresceu em cultivo em outubro. Foi encontrada em pedaços de galhos finos caídos sobre o chão da floresta indicando que ocorre no dossel da floresta em alta luminosidade. Distingue-se de A. nemorosa na coloração creme- amarelada da flores, pela inflorescência sustentar cerca de quatro a cinco flores e pela morfologia floral. Dentre as demais espécies é distinguida pelas características típicas da subtribo Pleurothalidiinae, tais como, porte reduzido, presença de cauloma unifoliado, sépalas laterais coalescentes lateralmente, sendo diferenciada dentro da subtribo pela coloração creme-amarelada das flores e pelo labelo trilobado.

2. Acianthera nemorosa (Barb. Rodr.) F. Barros, Hoehnea 30(3): 186. 2003.

Figuras $1 \mathrm{~b}, \mathrm{c}, 5 \mathrm{~b}$

Plantas epífitas. Rizoma 2-3 cm compr., caule não intumescido em pseudobulbo, do tipo cauloma. Cauloma 2,2-5,9 cm compr., unifoliado; bainhas do cauloma ca. 0,4 cm compr., tubulares, amplectivas. Folhas 6,4-8,7 × 1,7-2,2 cm, lanceoladas, verde escuras, ápice agudo. Inflorescência 2,5-3,2 cm compr., 3-flora, terminal, emergindo próxima a zona de abscisão da folha, uma por cauloma, floração simultânea; brácteas florais ca. $0,15 \times 0,2 \mathrm{~cm}$. Flores vináceas com traços amarelados na sépala dorsal e pétalas, pétalas vináceas; sépala dorsal ca. $0,8 \times 0,3 \mathrm{~cm}$, estreito-elíptica, ápice agudo; sépalas laterais ca. 0,7 ×0,3 cm, lanceoladas, ápice agudo, coalescentes lateralmente formando um sinsépalo; sinsépalo ca. 0,7 ×0,6 cm; pétalas ca. $0,25 \times 0,1 \mathrm{~cm}$, espatuladas, assimétricas, ápice agudo, base estreita, margem fimbriada; labelo ca. $0,4 \times 0,2 \mathrm{~cm}, 3$-lobado; lobos laterais ca. $0,2 \times 0,1 \mathrm{~cm}$; lobo terminal ca. $0,15 \times 0,2 \mathrm{~cm}$, arredondado; coluna ca. $0,3 \mathrm{~cm}$ compr., polínias 2 . Frutos não observados.

Material examinado: BRASIL. Espírito SANTo: Cachoeiro de Itapemirim, Distrito de Burarama, Barra Alegre, 3-I-2009, A.H. Krahl 161 (VIES); idem, 29-III-2009, A.H. Krahl 193 (VIES). 

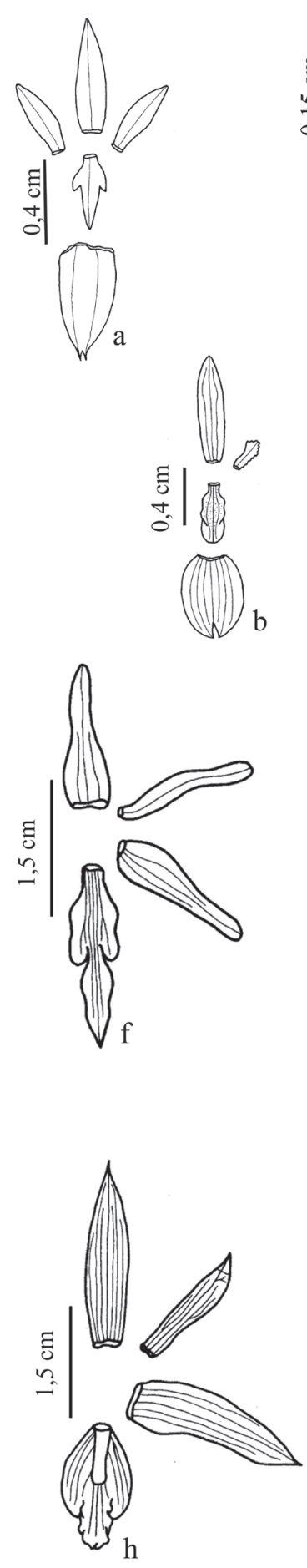

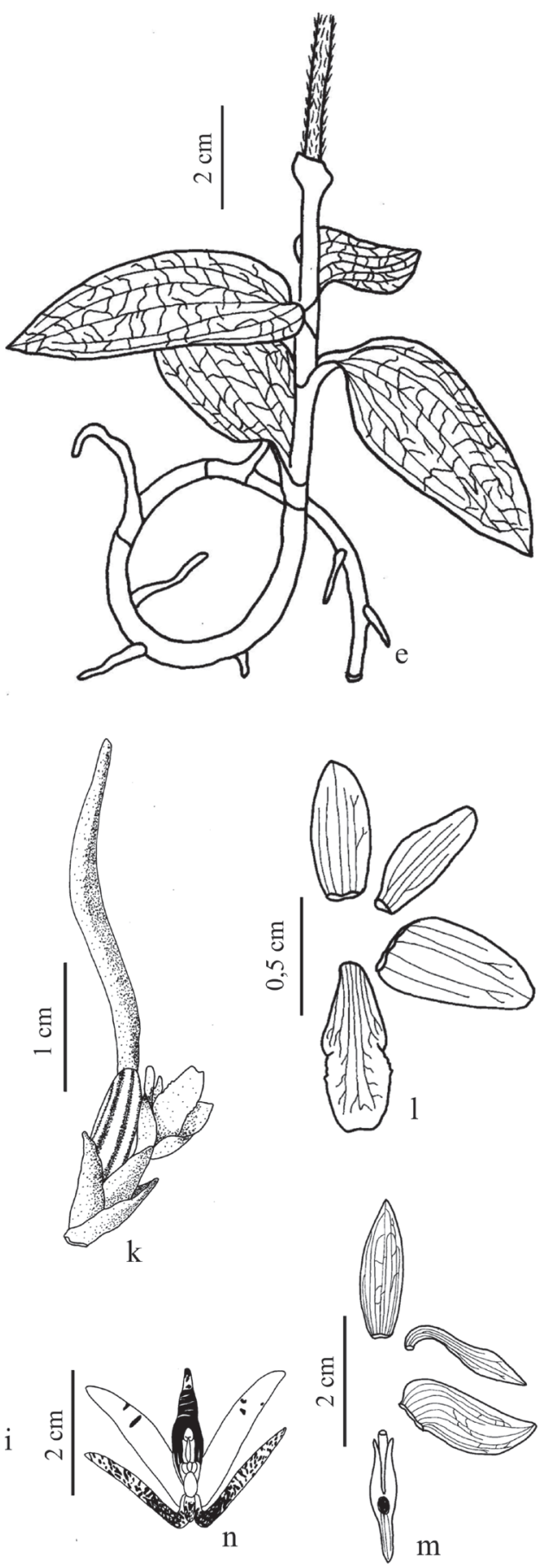

Figura 1. Espécies de Orchidaceae da região sul do Estado do Espírito Santo, Brasil. a. Acianthera capillaris. a. Peças florais. b-c. Acianthera nemorosa. b. Peças florais. c. Coluna. d-e. Aspidogyne argentea. d. Peças florais. e. Aspecto geral da planta. f-g. Aspidogyne mendoncae. f. Peças florais. g. Flor. h-j. Brasiliorchis consanguinea. h. Peças florais. i. Flor. j. Coluna. k-1. Christensonella pumila. k. Aspecto geral da planta. 1. Flor. m-n. Cirrhaea dependens. Peças florais. n. Flor.

Figure 1. Orchidaceae species in the southern Espírito Santo State, Brazil. a. Acianthera capillaris. a. Floral parts. b-c. Acianthera nemorosa. b. Floral parts. c. Column. d-e. Aspidogyne argentea. d. Floral parts. e. General appearance of the plant. f-g. Aspidogyne mendoncae. f. Floral parts. g. Flower. h-j. Brasiliorchis consanguinea. h. Floral parts. i. Flower. j. Column. k-1. Christensonella pumila. k. General appearance of the plant. 1. Flower. m-n. Cirrhaea dependens. Floral parts. n. Flower. 
Acianthera nemorosa está distribuída pelos Estados da BA, ES, MG e SP (Barros et al. 2013). Foi observada em flor entre os meses de janeiro e março, ocupando a parte média do tronco das árvores localizadas na borda da trilha principal com média intensidade luminosa, em altitudes próximas a 650 metros. Dentre as demais espécies é distinguida pelas características típicas da subtribo Pleurothalidiinae, tais como, porte reduzido, presença de cauloma unifoliado, sépalas laterais coalescentes lateralmente, sendo diferenciada, dentro da subtribo, pela presença de três flores de coloração vinácea com traços amarelados na sépala dorsal e pétala e pétalas com a margem fimbriada.

3. Aspidogyne argentea (Vell.) Garay, Bradea 2(28): 203. 1977.

Figuras 1 d, e, 5 c

Planta terrícola. Caule ca. $6,5 \mathrm{~cm}$ compr., não intumescido em pseudobulbo, alongado, cilíndrico. Folhas 8-10, 4,2-4,6 × 1,8-2 cm, ereto-patentes; lâmina foliar oval-lanceolada, ápice agudo, nervuras reticuladas e de coloração esbranquiçada; pseudopecíolo 0,9-1,2 cm compr., base formando bainha amplexicaule. Inflorescência ca. $14 \mathrm{~cm}$ compr., 13-16-flora, em racemo, pedúnculo piloso; brácteas florais ca. $0,8 \times 0,2 \mathrm{~cm}$, lanceoladas, pilosas, ápice acuminado. Flores brancas com listra acastanhada no meio das sépalas laterais e pétalas, calcaradas, concentradas no ápice da inflorescência; sépala dorsal ca. 0,5 × 0,2 cm, elíptica, ápice agudo; sépalas laterais ca. $0,7 \times 0,2 \mathrm{~cm}$, lanceoladas, ligeiramente falcadas, assimétricas, base estreita, ápice agudo; pétalas ca. $0,5 \times 0,1 \mathrm{~cm}$, espatuladas, assimétricas, base estreita, ápice agudo; calcar ca. 0,3 cm compr.; labelo ca. 0,7 ×0,2 cm, base estreita expandindo em uma lâmina 3-lobada; lobos laterais ca. 0,3 ×0,1 cm, hemielípticos, côncavos; lobo terminal ca. $0,2 \times 0,1 \mathrm{~cm}$, ápice com três proeminências; coluna ca. $0,3 \mathrm{~cm}$ compr., polínias 2 . Fruto não observado.

Material examinado: BRASIL. Espírito SAnto: Cachoeiro de Itapemirim, Distrito de Burarama, Barra Alegre, 12-X-2008, A.H. Krahl 128 (VIES).

Aspidogyne argentea está restrita no Brasil às regiões Sudeste e Sul, com ocorrência para os Estados da BA, ES, RJ, SP, PR, SC, RS (Barros et al. 2013) e DF (Batista \& Bianchetti 2003). Foi observada em flor durante o mês de outubro, desenvolvendo-se em locais sombreados com grande quantidade de matéria orgânica e grossa camada de serapilheira. É facilmente reconhecida pelas folhas dispostas ao longo do caule, lâmina foliar reticulada com as nervuras de coloração esbranquiçada, inflorescência ereta com flores concentradas no ápice e pelas flores de coloração alva com listras acastanhadas nas sépalas laterais e pétalas.

4. Aspidogyne mendoncae (Brade \& Pabst) Ormerod, Harvard Pap. in Bot. 13(1): 58. 2008.

Figuras $1 \mathrm{f}, \mathrm{g}, 5 \mathrm{~d}$

Planta terrícola. Caule ca. $15 \mathrm{~cm}$ compr., não intumescido em pseudobulbo, alongado, cilíndrico. Folhas 5-8, 6,1-7,9 × 2,2-3,1 cm, lanceoladas, ápice agudo, verde claras; pseudo-pecíolo 2,7-3,3 cm compr., base formando bainha amplexicaule. Inflorescência 8-8,5 cm compr., 16-flora, em racemo, apical, pedúnculo piloso; brácteas florais ca. 1,8 × 0,6 cm, lanceoladas, côncavas, pilosas, ápice acuminado. Flores verdes com pétalas e labelo alvos, uma mancha verde em cada lobo lateral do labelo, calcaradas; sépala dorsal ca. 1,4×0,4 cm, lanceolada, côncava, pilosa externamente, ápice acuminado; sépalas laterais ca. 1,5 ×0,4 cm, lanceoladas, ligeiramente assimétricas, pilosas externamente, ápice agudo; pétalas ca. 1,5 × 0,2 cm, lineares, ápice arredondado; calcar ca. 1,1 cm compr.; labelo ca. 1,7 $\times 0,5 \mathrm{~cm}, 3$-lobado, base estreita; lobos laterais ca. $0,5 \times 0,25 \mathrm{~cm}$, hemielípticos, levemente emarginados; lobo terminal ca. 0,6 $\times 0,25 \mathrm{~cm}$, lanceolado, côncavo, ápice agudo; coluna ca. $0,9 \mathrm{~cm}$ compr., polínias 2. Fruto não observado.

Material examinado: BRASIL. Espírito SAnto: Cachoeiro de Itapemirim, Distrito de Burarama, Barra Alegre, 29-III-2009, A.H. Krahl 189 (VIES).

Aspidogyne mendoncae é endêmica do ES (Barros et al. 2013). Na área de estudo, apenas um exemplar foi observado em flor no mês de março, desenvolvendo-se em serapilheira úmida e em local sombreado. A diferença em relação a $A$. argentea está no fato de não possuir lâmina foliar reticulada, e no tamanho e coloração das flores. Sendo assim, A. mendoncae possui altura aproximada de $15 \mathrm{~cm}$, enquanto que A. argentea apresenta cerca de $6,5 \mathrm{~cm}$ de altura. As flores de $A$. mendoncae são maiores (mais que $1 \mathrm{~cm}$ de comprimento) e de coloração verde nas sépalas e alva nas pétalas e labelo, enquanto que $A$. argentea possui flores menores (menos que $1 \mathrm{~cm}$ de comprimento) e 
exibem coloração branca com listra acastanhada no meio das sépalas laterais e pétalas. Dentre as demais espécies ocorrentes no fragmento florestal, esta pode ser distinguida também pela disposição das folhas ao longo do caule, flores externamente pilosas, pétalas lineares de coloração alva e labelo alvo com duas máculas verdes em cada lobo lateral.

5. Brasiliorchis consanguinea (Klotzsch) R. Singer, S. Koehler \& Carnevali, Novon 17(1): 96. 2007. Figuras 1 h-j, 5 e

Planta epífita, reptante. Rizoma 1,6-1,9 cm compr., coberto por catáfilos. Pseudobulbos 2,1-3,1 × 1-1,5 cm, ovóides, sulcados, amarelados, cobertos por duas bainhas das folhas laterais, 2-foliados. Folhas 8,6-13,3 × 1,6-1,9 cm, elípticas, conduplicadas, verdes, ápice agudo. Inflorescência 7,6-10,5 cm compr., lateral, uniflora, 4-6 por pseudobulbo; pedúnculo 5,7-7,7 cm compr.; brácteas do pedúnculo ca. $2 \times 0,4 \mathrm{~cm}$, lanceoladas, ápice agudo, amplectivas; bráctea floral ca. 1,8 $\times 0,6 \mathrm{~cm}$, lanceolada, amplectiva, ápice agudo. Flores com sépalas e pétalas amareladas matizadas de castanho se concentrado no ápice, labelo alvo com pontos arroxeados entre os lobos laterais; pedicelo e ovário 1,5-1,8 cm compr.; sépala dorsal ca. 1,9 × 0,6 cm, estreito-elíptica, côncava, ápice agudo; sépalas laterais ca. $2 \times 0,6 \mathrm{~cm}$, lanceoladas, ligeiramente curvas, ápice agudo; pétalas ca. 1,6 $\times 0,35 \mathrm{~cm}$, oblongo-elípticas, assimétricas, ápice agudo; labelo ca. 1,4 × 0,9 cm, 3-lobado, disco provido de uma calosidade longitudinal; lobos laterais ca. $0,7 \times 0,3 \mathrm{~cm}$, semicirculares; lobo terminal ca. $0,6 \times 0,4 \mathrm{~cm}$, oval, margem ondulada; coluna ca. $0,8 \mathrm{~cm}$ compr., polínias não vistas. Fruto não observado.

Material examinado: BRASIL. Espírito SAnto: Cachoeiro de Itapemirim, Distrito de Burarama, Barra Alegre, 3-I-2009, A.H. Krahl 146(VIES); idem, ibidem, A.H. Krahl 165 (VIES); idem, ibidem, A.H. Krahl 166 (VIES).

Brasiliorchis consanguinea até o momento está restrita à região Sudeste do Brasil, com ocorrência para os Estados do ES, MG, RJ e SP (Barros et al. 2013). A espécie é comum em locais com intensa luminosidade e floresce durante os meses de janeiro e fevereiro. É reconhecida pelos pseudobulbos bifoliados notavelmente amarelados, pétalas e sépalas amareladas com leve coloração acastanhada em direção ao ápice e labelo alvo com pontuações arroxeadas.
6. Christensonella pumila (Hook.) Szlach., Mytnik, Górniak \& Smiszek., Polish Bot. J. 51(1): 58. 2006. Figuras $1 \mathrm{k}, 1,5 \mathrm{f}$

Planta epífita, cespitosa. Rizoma 0,5-0,7 cm compr., recoberto por catáfilos. Pseudobulbos 1-1,2 × 0,3-0,6 cm, cônicos, sulcados, unifoliados, verde-escuros. Folha 3,3-4,1 × 0,3-0,5 cm, oblongolanceolada, crassa, verde escura, ápice agudo. Inflorescência 0,9-1,2 cm compr., lateral, uniflora; bráctea floral ca. $0,5 \times 0,2 \mathrm{~cm}$, lanceolada, ápice agudo. Flores vináceas; pedicelo e ovário ca. $0,6 \mathrm{~cm}$ compr.; ca. sépala dorsal $0,6 \times 0,3 \mathrm{~cm}$, ovada, côncava, ápice arredondado; sépalas laterais ca. 0,8 $\times 0,4 \mathrm{~cm}$, ovadas, assimétricas, ápice arredondado; pétalas ca. 0,6 $\times 0,2 \mathrm{~cm}$, linear-liguladas, ápice arredondado; labelo ca. 0,7 ×0,3 cm, 3-lobado, disco provido de uma calosidade longitudinal; lobos laterais ca. $0,15 \times 0,1 \mathrm{~cm}$, arredondados; lobo terminal ca. $0,4 \times 0,3 \mathrm{~cm}$, arredondado, margem superior ligeiramente ondulada, ápice retuso; coluna ca. $0,5 \mathrm{~cm}$ compr., polínias não vistas. Fruto não observado.

Material examinado: BRASIL. Espírito SANTo: Cachoeiro de Itapemirim, Distrito de Burarama, Barra Alegre, 14-IX-2008, A.H. Krahl 110 (VIES).

A distribuição de C. pumila ocorre de forma disjunta entre as regiões Sudeste e Sul e a região Norte, com registros para os Estados do AM, AP, RO, ES, MG, RJ, SP, PR e SC (Barros et al. 2013). $\mathrm{Na}$ área de estudo, a espécie foi observada com um pequeno número de exemplares, vegetando no mesmo habitat de Grandiphyllum auricula. A floração foi observada no mês de setembro e pode ser distinguida das demais espécies pelo porte pequeno e cespitoso, flores vináceas, labelo trilobado com o lobo terminal apresentando a margem superior levemente ondulada e ápice retuso.

7. Cirrhaea dependens Loudon, Hort. Brit.: 370. 1850. Figuras $1 \mathrm{~m}, \mathrm{n}, 5 \mathrm{~g}$

Planta epífita ou rupícola, cespitosa. Rizoma inconspícuo. Pseudobulbos 4,2-5,1 × 2,4-2,9 cm, ovais, sulcados, unifoliados, verde-escuros. Folha 27,3-40,5 × 2,6-5,1 cm, linear-lanceolada, subcoriácea, plicada, verde-escura, peciolada, ápice agudo, pecíolo canaliculado. Inflorescência 16,6-20,5 cm compr., em racemo, lateral, pendente, 10-15-flora; pedúnculo $7-13 \mathrm{~cm}$ compr. Flores amarelas a vináceas, com listras acastanhados concentrados nas pétalas e labelo, pouca concentração nas sépalas; sépala 
dorsal ca. 2,8 × 0,8 cm, oblanceolada, ápice agudo; sépalas laterais $2,5 \times 0,8 \mathrm{~cm}$, lanceoladas, inflexas, assimétricas, ápice agudo, base encurvada; pétalas ca. 2,1 ×0,3 cm, linear-lanceoladas, inflexas, ápice agudo, base encurvada e estreita; labelo ca. $2 \times 0,4 \mathrm{~cm}$, carnoso, unguiculado, 3-lobado, disco com uma calosidade orbicular de ca. 0,2 cm diâm.; lobos laterais ca. $0,9 \times 0,2 \mathrm{~cm}$, linear-lanceolados, ligeiramente falcados, ápice agudo; lobo terminal ca. 0,6 $\times 0,2 \mathrm{~cm}$, lanceolado, ápice arredondado; coluna ca. $1,4 \mathrm{~cm}$ compr., polínias 2. Fruto não observado.

Material examinado: BRASIL. Espírito SAnto: Cachoeiro de Itapemirim, Distrito de Burarama, Barra Alegre, 3-I-2009, A.H. Krahl 147 (VIES); idem, ibidem, A.H. Krahl 148 (VIES).

No território brasileiro, $C$. dependens ocorre nos Estados da BA, ES, MG, RJ, SP, PR e SC (Barros et al. 2013). Na área de estudo, esta espécie é muito comum em rochas e árvores localizadas ao longo do curso d'água principal. A floração foi observada nos meses de janeiro e fevereiro e assim como observado por Romanini \& Barros (2007), suas flores possuem um colorido variável que inclui tons de vermelho, vináceo e amarelo, com pintas e traços avermelhados ou vináceos. A espécie pode ser diferenciada das demais ocorrentes na área de estudo pela presença de sépalas laterais e pétalas inflexas, e pelo labelo unguiculado, trilobado e com o disco portando um calo orbicular.

8. Eltroplectris janeirensis (Porto \& Brade) Pabst, Bradea 1(47): 469. 1974.

Figuras $2 \mathrm{a}-\mathrm{d}, 5 \mathrm{~h}$

Planta terrícolas, unifoliadas. Caule não intumescido em pseudobulbo, reduzido. Folhas longopecioladas; pecíolo róseo a vináceo, $21,6-24,5 \mathrm{~cm}$, profundamente canaliculado; bráctea da base do pecíolo $3,2 \times 1,2 \mathrm{~cm}$, lanceolada, ápice agudo; lâmina foliar 15,5-17,2 × 9,9-11,6 cm, verde-escura, com a região da nervura verde claro, ovada, ápice acuminado, base arredondada e atenuada, algumas vezes assimétrica. Inflorescência 39,9-59,4 cm compr., 12-18-flora, ereta, terminal; pedúnculo róseo a vináceo, ereto; brácteas do pedúnculo $2-2,4 \times 1,1 \mathrm{~cm}$, lanceoladas, acastanhadas, ápice agudo; brácteas florais 1,6-1,9 × 0,5-0,7 cm, lanceoladas, ápice agudo. Flores creme, sésseis, calcaradas; sépala dorsal ca. 1,1 ×0,4 cm, lanceolada, côncava, ápice agudo; sépalas laterais ca. 1,3 ×0,4 cm, lanceoladas, ligeiramente falcadas, ápice agudo,; pétalas ca. $1 \times 0,4 \mathrm{~cm}$, lanceoladas, ligeiramente falcadas e assimétricas, ápice agudo; calcar ca. 1,3 × 0,4 cm; labelo ca. 1,8 $\times 0,6 \mathrm{~cm}$, base estreita e oblonga, expandido a partir do meio em lâmina 3-lobada; lobos laterais ca. $0,5 \times 0,3 \mathrm{~cm}$, semicirculares; lobo terminal ca. $0,5 \times 0,3 \mathrm{~cm}$, lanceolado, ápice agudo; coluna ca. 0,6 cm compr., polínias 2, claviformes. Fruto 1,6-2 cm compr., acastanhado.

Material examinado: BRASIL. Espírito SANTo: Cachoeiro de Itapemirim, Distrito de Burarama, Barra Alegre, 20-IV-2008, A.H. Krahl 24 (VIES); idem, ibidem, A.H. Krahl 25 (VIES).

A princípio, E. janeirensis era conhecida apenas nos Estados do RJ e MG (Barros et al. 2013), sendo este o primeiro registro para o Estado do Espírito Santo, descoberta que justifica a importância dos trabalhos taxonômicos e florísticos para o Estado, principalmente em regiões carentes em trabalhos técnico-científicos. Na área de estudo foram encontradas duas populações que floresceram no mês de abril e sua frutificação se sucedeu a partir de junho. Os exemplares foram observados em locais sombreados e em solos de textura areno-argilosa. A espécie é facilmente reconhecida pelo hábito terrícola, folhas longo-pecioladas, pecíolo profundamente canaliculado, lâmina foliar ovada e verde escura com a região das nervuras em verde claro e pela inflorescência em racemo portando flores calcaradas de coloração creme com labelo trilobado.

9. Eltroplectris triloba (Lind.) Pabst, Bradea 1(47): 470. 1974.

Figuras 2 e-g, 5 i

Plantas terrícolas, unifoliadas. Caule não intumescido em pseudobulbo, reduzido. Folhas longopecioladas; pecíolo 19,9-22,9 cm, sem canalículo ou levemente canaliculado, róseo a vináceo; bráctea da base do pecíolo $2,1 \times 0,7 \mathrm{~cm}$, lanceolada, ápice agudo; lâmina foliar 18,4-22,9 × 5,8-7,9 cm, verdeescura, lanceolada, ápice agudo, base atenuada. Inflorescência 46-60 cm compr., ereta, 16-22-flora; pedúnculo amarronzado, ereto; brácteas do pedúnculo 2,7-3 × 0,6-0,8 cm lanceoladas, ápice agudo; brácteas florais 1,7-2 × 0,6-0,7 cm, lanceoladas, ápice acuminado. Flores esverdeadas, sésseis, calcaradas; sépala dorsal ca. $1 \times 0,4 \mathrm{~cm}$, lanceolada, côncava, ápice acuminado; sépalas laterais ca. 1,3 ×0,4 cm, lanceoladas, falciformes, ápice acuminado; pétalas 

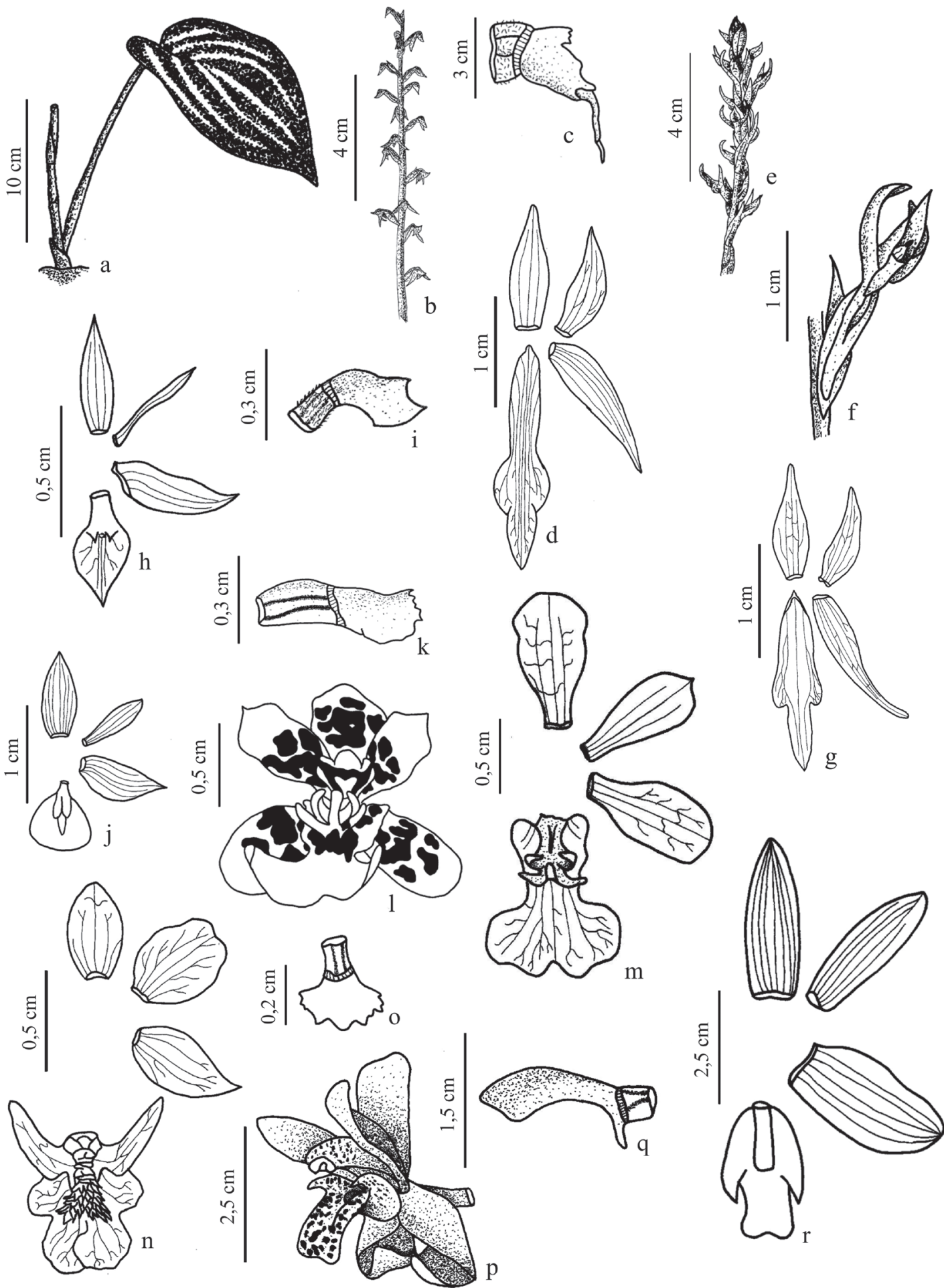

Figura 2. Espécies de Orchidaceae da região sul do Estado do Espírito Santo, Brasil. a-d. Eltroplectris janeirensis. a. Aspecto geral da planta. b. Inflorescência. c. Coluna. d. Peças florais. e-g. Eltroplectris triloba. e. Inflorescência. f. Flor. g. peças florais. h-i. Epidendrum avicula. h. Peças florais. i. Coluna. j-k. Epidendrum hololeucum. j. Peças florais. k. Coluna. 1-m. Grandiphyllum auricula. 1. Flor. m. peças florais. n-o. Lockhartia lunifera. n. Peças florais. o. Coluna. p-r. Mormolyca rufescens. p. Flor. q. Coluna. r. peças florais.

Figure 2. Orchidaceae species in the southern Espírito Santo State, Brazil. a-d. Eltroplectris janeirensis. a. General appearance of the plant. b. Inflorescence. c. Column. d. Floral parts. e-g. Eltroplectris triloba. e. Inflorescence. f. Flower. g. Floral parts. h-i. Epidendrum avicula. h. Floral parts. i. Column. j-k. Epidendrum hololeucum. j. Floral parts. k. Column. 1-m. Grandiphyllum auricula. 1. Flower. m. Floral parts. n-o. Lockhartia lunifera. n. Floral parts. o. Column. p-r. Mormolyca rufescens. p. Flower. q. Column. r. Floral parts. 
ca. $0,8 \times 0,3 \mathrm{~cm}$, lanceoladas, ligeiramente falciformes e assimétricas, ápice agudo; calcar ca. 1,2 ×0,3 cm; labelo ca. 1,5 $\times 0,5 \mathrm{~cm}$, expandido a partir do meio em uma lâmina 3-lobado; lobos laterais ca. 0,4 ×0,2 cm, arredondados; lobo terminal ca. 0,6 $\times 0,3 \mathrm{~cm}$, lanceolado, ápice agudo; coluna ca. 0,5 cm compr., polínias 2, claviformes. Fruto não observado.

Material examinado: BRASIL. Espírito SAnto: Cachoeiro de Itapemirim, Distrito de Burarama, Barra Alegre, 10-VIII-2008, A H. Krahl 99 (VIES).

Eltroplectris triloba possui ocorrência para os Estados do BA, ES, RJ e SP (Barros et al. 2013). $\mathrm{Na}$ área de estudo sua população está composta por poucos indivíduos, os quais podem ser encontrados na camada de liteira formada próxima à base de um dos afloramentos rochosos. A floração ocorre nos meses de agosto e setembro, e a espécie pode ser reconhecida pela presença de folhas longo-pecioladas, flores calcaradas de coloração esverdeada e pelo labelo trilobado. Distingue-se de E. janeirensis pela morfologia floral (formato do lobos laterais) e pela ausência do pecíolo profundamente canaliculado.

10. Epidendrum avicula Lindl., J. Bot. (Hooker) 3: 85. 1841.

Figuras 2 h, i, 5 j

Planta epífita, reptante. Rizoma 1,8-2,5 cm compr., envolto por bainhas. Pseudobulbos 2-3,5 $\times 0,7-1 \mathrm{~cm}$, fusiformes, envoltos por bainhas, 2-3-foliados, verdes. Folhas 3,9-4,5 × 0,7-1,2 cm, elípticas, verdes, ápice agudo. Inflorescência 4,6-9,8 cm compr., em panícula, ereta, 9-29-flora; pedúnculo 2-2,8 cm compr.; brácteas do pedúnculo ca. $0,4 \times 0,1 \mathrm{~cm}$, lanceoladas, ápice agudo; brácteas florais ca. $0,2 \times 0,15 \mathrm{~cm}$, lanceoladas, ápice agudo. Flores amareladas a esverdeadas; sépala dorsal ca. $0,4 \times 0,15 \mathrm{~cm}$, elíptica, pilosa na face externa, ápice agudo; sépalas laterais ca. 0,4 ×0,15 cm, lanceoladas, subfalcadas, pilosas na face externa, ápice agudo; pétalas ca. $0,4 \times 0,05 \mathrm{~cm}$, lineares, encurvadas, ápice agudo; labelo ca. 0,4 ×0,3 cm, inteiro, ovado, ápice acuminado, base estreitada, disco com um calo bidentado; coluna ca. 0,3 cm compr., polínias 4 , em 2 pares desiguais. Fruto não observado.

Material examinado: BRASIL. Espírito Santo: Cachoeiro de Itapemirim, Distrito de Burarama, Barra Alegre, 22-II-2009, A.H. Krahl 180 (VIES).

Epidendrum avicula possui ampla distribuição dentro do território brasileiro e pode ser encontrada nos Estados do CE, PB, PB, DF, GO, MT, ES, MG, RJ, SP, PR, SC e RS (Barros et al. 2013). Comumente, aparece identificada nos herbários como Lanium avicula, nome proposto por Bentham (1881) que elevou à categoria de gênero as espécies de Epidendrum seção Lanium Lindl. Contudo, Dressler (1967) propôs a transferência de todas as espécies para Epidendrum, posição que é adotada neste trabalho. $\mathrm{Na}$ área de estudo, exemplares são encontrados em locais de clareira e florescem nos meses de fevereiro e março. Epidendrum avicula se diferencia das demais espécies ocorrentes na área de estudo pela grande quantidade de flores na inflorescência, cuja coloração varia do amarelo ao esverdeado, sépalas tomentosas na face externa, e pelo labelo inteiro com o disco provido de uma calosidade bidentada.

11. Epidendrum hololeucum Barb. Rodr., Gen. Sp. Orchid. 2: 145. 1881.

Figuras $2 \mathrm{j}, \mathrm{k}, 5 \mathrm{k}$

Planta epífita. Rizoma inconspícuo. Caule não espessado em pseudobulbo, 22,7-28,6 cm compr., ereto, alongado, cilíndrico, 5-6-foliado. Folhas 10,4-15,2 cm, verdes, estreito-elípticas, concentradas na porção distal do caule, ápice acuminado. Inflorescência 3,9-5,9 cm compr., em racemo, 1-3-flora; pedúnculo 1,9-2,5 cm; bráctea do pedúnculo ca. $0,7 \times 0,4 \mathrm{~cm}$, lanceolada, ápice agudo; brácteas florais ca. $0,5 \times 0,3 \mathrm{~cm}$, lanceoladas, ápice agudo. Flores alvas, glabras; sépala dorsal ca. 0,8 $\times 0,4 \mathrm{~cm}$, elíptica, ápice agudo; sépalas laterais ca. $0,9 \times 0,4 \mathrm{~cm}$, lanceolada, assimétrica, ápice agudo; pétalas ca. $0,7 \times 0,2 \mathrm{~cm}$, oblanceoladas, ápice agudo; labelo 0,5 $\times 0,6 \mathrm{~cm}$, inteiro, ovado, carnoso, base estreita, disco provido de 3 calos longitudinais; coluna ca. $0,3 \mathrm{~cm}$ compr., polínias 4 . Fruto não observado.

Material examinado: BRASIL. Espírito SANTo: Cachoeiro de Itapemirim, Distrito de Burarama, Barra Alegre, 25-V-2008, A.H. Krahl 49 (VIES).

Epidendrum hololeucum é uma espécie de distribuição restrita à Mata Atlântica da região Sudeste do Brasil, com ocorrência descrita para os Estados do RJ e SP (Barros et al. 2013). A partir de material depositado no herbário MBML pode-se constatar a sua ocorrência para o Estado do ES. Na área estudada, o exemplar foi observado desenvolvendo-se sobre árvores ao longo de curso d'água e floresceu no mês de maio. A espécie é reconhecida por possuir folhas ao longo do caule e concentradas na sua porção distal, flores alvas e labelo inteiro com o disco provido de três calos. 
12. Grandiphyllum auricula (Vell.) Docha Neto, Colet. Orquídeas Brasil 3: 75. 2006.

Figuras 2 1, m, 51

Plantas epífitas, cespitosas. Rizoma 0,3-0,5 cm compr. Pseudobulbos 1,3-2,2 × 1,6-2,7 cm, ovóides, achatados lateralmente, unifoliados, verde-claros. Folha 8,9-13,4 × 1,5-2,3 cm, oblongo-elíptica, crassa, conduplicada, verde pálido, ápice levemente agudo. Inflorescência 31,7-32,9 cm compr., em panícula, lateral, 16-20-flora; pedúnculo 17,1-22,1 cm compr. Flores amarelas pintalgadas de castanho, pediceladas; pedicelo 1,3-15 cm compr.; sépala dorsal ca. $0,8 \times 0,5 \mathrm{~cm}$, ovada, côncava, base estreita, ápice obtuso; sépalas laterais ca. $0,8 \times 0,3 \mathrm{~cm}$, ovadas, base estreita, ápice arredondado; pétalas ca. $0,8 \times 0,3 \mathrm{~cm}$, oblanceoladas, assimétricas, ápice agudo; labelo ca. $0,8 \times 0,9 \mathrm{~cm}, 2$-lobado, disco provido de cinco calos digitiformes; lobos ca. $0,35 \times 0,4 \mathrm{~cm}$, arredondados, margem emarginada; coluna ca. $0,2 \mathrm{~cm}$ compr., alada, polínias 4. Fruto não observado.

Material examinado: BRASIL. Espírito Santo: Cachoeiro de Itapemirim, Distrito de Burarama, Barra Alegre, 29-III-2009, A H. Krahl 190 (VIES); idem, ibidem, A H. Krahl 191 (VIES).

Grandiphyllum auricula está distribuído pelos Estados do ES, MG, RJ e SP (Barros et al. 2013). $\mathrm{Na}$ área estudada, G. auricula pode ser distinguida das demais espécies pelos pseudobulbos ovoides, achatados lateralmente e unifoliados, inflorescência pendente e paniculada, flores amarelas e pintalgadas de castanho e labelo bilobado com o disco provido de cinco calos digitiformes. Um número reduzido de exemplares dessa espécie foi observado sobre troncos caídos em uma clareira à beira da trilha principal e sua floração ocorreu no mês de março.

A espécie é comumente conhecida pelo seu sinônimo Oncidium harrisonianum cuja transferência foi proposta para outro gênero denominado Aurinocidium por Romowicz \& Szlachetko (2006). Essa proposta de mudança ocorreu no mesmo ano no qual $O$. auricula foi transferida para o gênero Grandiphyllum por Docha-Neto et al. (2006). Assim como Romowicz \& Szlachetko (2006), Docha-Neto et al. (2006) tiveram o intuito de abranger espécies das seções de Oncidium citadas anteriormente. Contudo optou-se em manter a posição adotada por Docha-Neto et al. (2006) e aceita segundo a lista de espécies da Flora do Brasil (Barros et al. 2013).
13. Lockhartia lunifera Rchb. f., Bot. Zeitung (Berlin) 10: 767.1852.

Figuras 2 n, o, $5 \mathrm{~m}$

Plantas epífitas, cespitosas. Rizoma inconspícuo. Caule não espessado em pseudobulbo, 16,2-21,8 cm compr., alongado, cilíndrico, pendente ou ereto, multifoliado, totalmente recoberto pela base das folhas. Folhas 1,2-2,1 ×0,3-0,5 cm, triangulares, achatadas lateralmente, dísticas, imbricadas, verdes, ápice arredondado, bainhas em invaginantes. Inflorescência lateral, uniflora, 1-5 por caule; brácteas florais 0,3-0,4 cm compr., cordiformes. Flores amareladas com máculas acastanhadas no labelo; sépala dorsal ca. $0,5 \times 0,3 \mathrm{~cm}$, ovada, côncava, ápice arredondado; sépalas laterais ca. $0,6 \times 0,3 \mathrm{~cm}$, ovada, côncavas, ligeiramente assimétricas, ápice agudo; pétalas ca. $0,6 \times 0,4 \mathrm{~cm}$, ovadas, ápice retuso, margem levemente ondulada; labelo ca. $0,8 \times 0,7 \mathrm{~cm}$, disco com um calo papiloso, 5-lobado; lobos da base ca. 0,5 $\times 0,15 \mathrm{~cm}$, lineares, ápice arredondado; lobos medianos ca. 0,2 $\times 0,2 \mathrm{~cm}$, triangulares a arredondados, retrorsos, ápice arredondado; lobo central ca. $0,35 \times 0,2 \mathrm{~cm}$, arredondado, bilobulado; coluna ca. $0,2 \mathrm{~cm}$ compr., alada, polínias 2 . Fruto não observado.

Material examinado: BRASIL. Espírito SANTo: Cachoeiro de Itapemirim, Distrito de Burarama, Barra Alegre, 3-I-2009, A.H. Krahl 170 (VIES).

No território brasileiro, L. lunifera está distribuída pelos Estados do AM, PA, MA, PB, AL, SE, BA, ES, MG, RJ, SP, PR, SC e RS (Barros et al. 2013). A espécie é comum no interior da área de estudo, principalmente em árvores ao longo do curso d'água. A floração dos exemplares ocorreu entre os meses de dezembro e fevereiro. Lockhartia lunifera é facilmente reconhecida por apresentar todo o caule recoberto por folhas persistentes, achatadas lateralmente e de base imbricante, além de ser a única com seis lobos no labelo e disco com calo papiloso.

14. Mormolyca rufescens (Lind1.) M.A. Blanco, Lankesteriana 7(3): 531. 2007.

Figuras 2 p-r, 5 n

Planta epífita. Rizoma 0,8-1,1 cm compr., entre os pseudobulbos. Pseudobulbos ca. 4,2 × 1,8 cm, ovóides, lateralmente achatados, unifoliados, verde claros. Folhas 14,5-17,2 × 2,4-3,2 cm, estreitoelípticas, conduplicadas, verde-claras, ápice agudo. Inflorescência ca. 5,3 cm compr., mais longa que 
o pseudobulbo, uniflora; brácteas do pedúnculo ca. 1,6 $\times 1,1 \mathrm{~cm}$, espaçadas, envolvendo o pedúnculo. Flores vermelhas a alaranjadas com máculas vináceas no labelo e coluna, carnosas; sépala dorsal ca. 2,4 ×0,9 cm, elíptica, ápice arredondada; sépalas laterais ca. $2,3 \times 1 \mathrm{~cm}$, lanceoladas, ligeiramente recurvadas, ápice arredondado; pétalas ca. 2,2 $\times 0,7 \mathrm{~cm}$, lanceoladas, ligeiramente assimétricas, ápice ligeiramente agudo; labelo ca. 1,9 ×0,8 cm, 3-lobado, disco provido de uma calosidade longitudinal; lobos laterais ca. $0,3 \times 0,15 \mathrm{~cm}$, dentados, ápice agudo, falcados; lobo terminal ca. $0,9 \times 0,7 \mathrm{~cm}$, oblongo, retangular, ápice truncado, margens arredondadas; coluna ca. 1,5 cm compr., polínias 4 . Fruto não observado.

Material examinado: BRASIL. Espírito Santo: Cachoeiro de Itapemirim, Distrito de Burarama, Barra Alegre, 10-VIII-2008, A H. Krahl 108 (VIES).

A espécie pertencia anteriormente ao gênero Maxillaria, tendo sido posteriormente transferida para Mormolyca por Blanco et al. (2007). Estes autores propuseram a transferência para este gênero as espécies que pertenciam ao gênero Chrysocycnis e à seção Rufescens do gênero Maxillaria. Mormolyca rufescens possui ampla distribuição, com a ocorrência descrita para os Estados do AC, AM, PA, RR, RO, MA, PB, BA, MT, ES, MG, RJ, SP, PR, SC e RS (Barros et al. 2013). O exemplar foi encontrado em agosto no dossel de uma árvore ao lado do curso d'água principal. A espécie pode ser reconhecida por apresentar pseudobulbos lisos e unifoliados, flores vermelhas a alaranjadas com o labelo trilobado apresentando máculas vinosas, lobos laterais dentados e terminal oblongo a retangular com o ápice truncado.

15. Octomeria juncifolia Barb. Rodr., Gen. Sp. Orchid. 2: 110. 1882.

Figuras 3 a, 5 o

Planta epífita, cespitosa. Rizoma ca. 0,3 cm compr. Caule não intumescido em pseudobulbo, 8-10 × 0,4-0,5 cm, 2-3-articulado, unifoliado, cilíndrico, verde. Folha 24,9-32,2 × 0,4-0,6 cm, cilíndrica, canaliculada, crassa, verde, podendo ocorrer pigmentação arroxeada, ápice agudo. Inflorescência ca. 1,8 cm compr., 2-5-flora. Flores amarelas, pediceladas; pedicelo ca. $0,7 \mathrm{~cm}$ compr.; sépalas dorsal ca. $1 \times 0,4 \mathrm{~cm}$, elíptica, ápice arredondado; sépalas laterais ca. $0,9 \times 0,4 \mathrm{~cm}$, oblongas, ápice arredondado, base curtamente coalescentes na base; pétalas ca. $1 \times 0,3 \mathrm{~cm}$, elípticas a estreitamente elípticas, ápice arredondado; labelo ca. $0,5 \times 0,35 \mathrm{~cm}$, 3 lobado, com pequenas máculas vinosas laterais na base; lobos laterais ca. $0,1 \times 0,1 \mathrm{~cm}$, orbiculares, lobo terminal ca. $0,3 \times 0,3 \mathrm{~cm}$, ovado, margem inteira, 2-dentado, ápice emarginado; coluna ca. 0,4 cm compr., polínias 8 . Fruto não observado.

Material examinado: BRASIL. Espírito SANTo: Cachoeiro de Itapemirim, Distrito de Burarama, Barra Alegre, 14-IX-2008, A.H. Krahl 111 (VIES).

Octomeria juncifolia ocorre nos Estados do ES, RJ, SP, PR, SC e RS (Barros et al. 2013). Dentre as demais espécies encontradas, esta se diferencia principalmente pela presença de folhas cilíndricas e canaliculadas, flores amarelas e sépalas laterais curtamente coalescentes na base. A floração ocorreu no mês de setembro e foi observada nos estratos superiores das árvores, em locais com intensa luminosidade.

16. Octomeria tricolor Rchb. f., Gard. Chron.: 1035. 1872.

Figuras 3 b, c, 5 p

Plantas epífitas, cespitosas. Rizoma inconspícuo. Caule não intumescido em pseudobulbo, cauloma. Cauloma 4,2-6,9 cm compr., cilíndrico, verde, unifoliado, geralmente todo recoberto por bainhas; bainhas do cauloma 1,1-3,2 cm de compr., tubulares, amplexicaule, geralmente escariosas, ápice agudo. Folha 5,2-9,2 × 0,9-1,4 cm, estreito-elíptica, verde, conduplicada, ápice agudo. Inflorescência 0,9-0,7 cm compr., 1-3-flora; brácteas florais 0,1-0,2 cm compr., amplectivas, ápice agudo. Flores com pétalas e sépalas alvas e labelo de coloração amarela na base e vermelha no ápice, pediceladas; pedicelo $0,1-0,2 \mathrm{~cm}$ compr.; sépala dorsal ca. $0,5 \times 0,2 \mathrm{~cm}$, lanceolada, ápice agudo; sépalas laterais ca. 0,5 × 0,15 cm, lanceoladas, ápice agudo; pétalas ca. 0,5 ×0,1 cm, estreito-elípticas, ligeiramente curva próximo no ápice, ápice agudo; labelo ca. 0,2 × 0,15 cm, 3-lobado, disco com duas calosidades, base estreitada; lobos laterais $0,05 \mathrm{~cm}$ compr., arredondados; lobo terminal ca. $0,15 \times 0,15 \mathrm{~cm}$, ovado, ápice arredondado, margem erosa; coluna ca. $0,15 \mathrm{~cm}$ compr., polínias não vistas. Fruto não observado.

Material examinado: BRASIL. Espírito SANTo: Cachoeiro de Itapemirim, Distrito de Burarama, Barra Alegre, 3-I-2009, A.H. Krahl 168(VIES); idem, ibidem, A.H. Krahl 169 (VIES). 

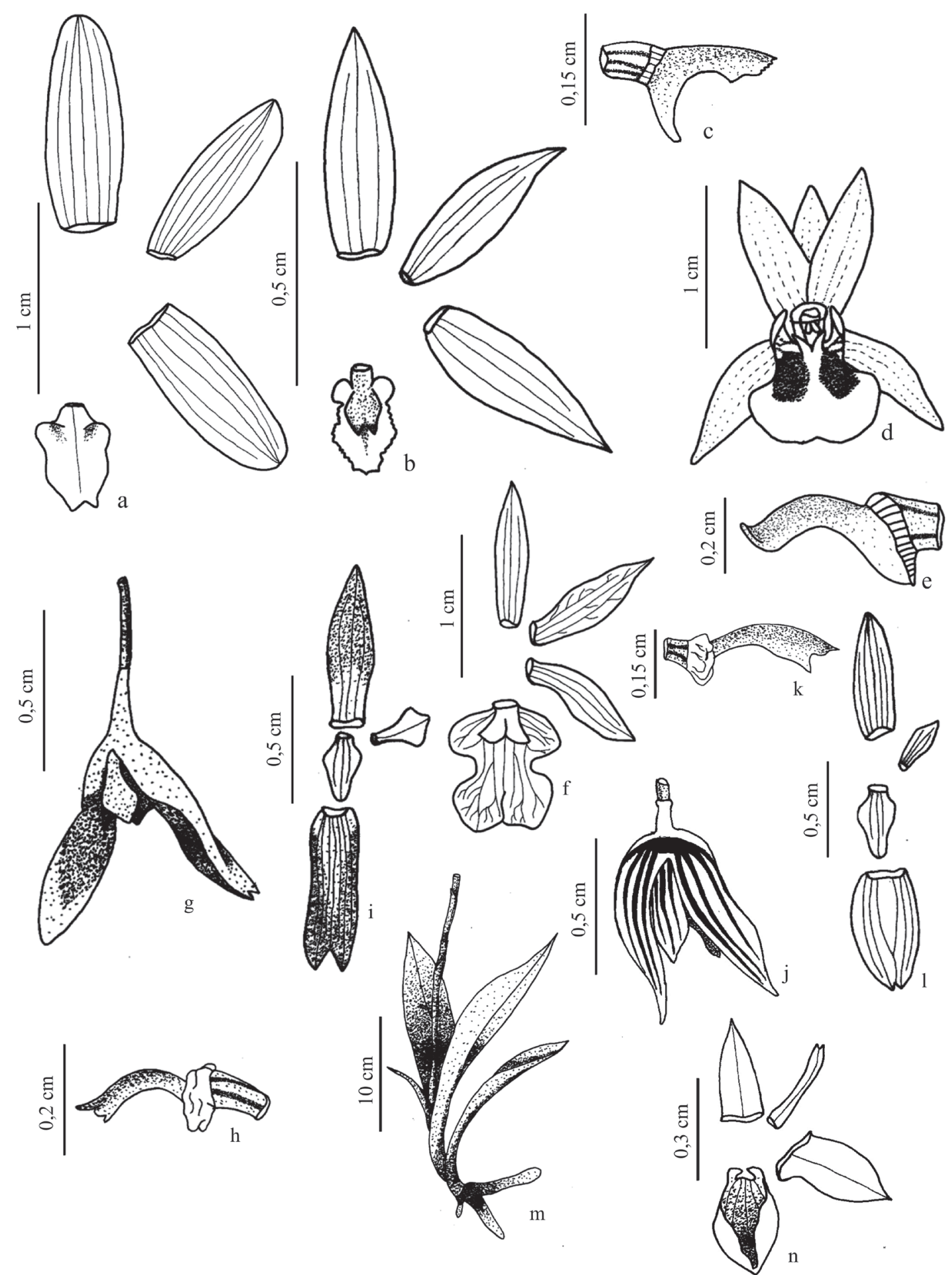

Figura 3. Espécies de Orchidaceae da região sul do Estado do Espírito Santo, Brasil. a. Octomeria juncifolia. a. Peças florais. b-c. Octomeria tricolor. b. Peças florais. c. Coluna. d-f. Oeceoclades maculata. d. Flor. e. Coluna. f. Peças florais. g-i. Pabstiella hians. g. Flor. i. Peças florais. h. Coluna. j-1. Pabstiella trifida. j. Flor. k. Coluna. 1. Peças florais. m-n. Prescottia plantaginifolia. m. Aspecto geral da planta. n. Peças florais.

Figure 3. Orchidaceae species in the southern Espírito Santo State, Brazil. a. Octomeria juncifolia. a. Floral parts. b-c. Octomeria tricolor. b. Floral parts. c. Column. d-f. Oeceoclades maculata. d. Flower. e. Column. f. Floral parts. g-i. Pabstiella hians. g. Flower. i. Floral parts. h. Column. j-1. Pabstiella trifida. j. Flower. k. Column. 1. Floral parts. m-n. Prescottia plantaginifolia. m. General appearance of the plant. n. Floral parts. 
Octomeria tricolor possui distribuição nas regiões Sul e Sudeste do Brasil, ocorrendo nos Estados do ES, RJ, SP e RS (Barros et al. 2013). Espécie comum em árvores ao longo de todo percurso da área de estudo, sua floração ocorreu no mês de janeiro. A espécie é reconhecida pelas flores alvas, labelo amarelo-avermelhado, trilobado e lobo terminal com margem erosa. A diferença com $O$. juncifolia está principalmente nas folhas cilíndricas e canaliculadas, em contraste com as folhas planas e conduplicadas de O. tricolor, além de se diferenciarem pela coloração das flores.

17. Oeceoclades maculata (Lindl.) Lindl., Gen. Sp. Orchid. P1.: 237. 1833.

Figuras 3 d-f, 5 q

Plantas terrícolas. Rizoma ca. 0,2 cm compr. Psedobulbos 1,5-3 × 1,1-1,6 cm, ovóides, envoltos por catáfilos, unifoliados, verde escuros. Folhas 12,8-22,6 × 3,3-3,9 cm, elípticas, coriáceas, conduplicadas, verde-claras com mácula verdeescura, ápice agudo. Inflorescência 31,1-41,2 cm compr., lateral, ereta, em racemo, 5-8-flora; pedúnculo 25,2-33,1 cm compr., ereto, verde escuro; brácteas do pedúnculo 2,1-3,5 × 0,4-0,5 cm, ovadas, amplectivas, ápice agudo; brácteas florais ca. 0,7 ×0,2 cm, lanceoladas a triangulares, ápice agudo. Flores de coloração creme-esverdeado a creme-rosadas, labelo alvo com duas máculas rosa na base, calcaradas, pediceladas; pedicelo ca. $0,4 \mathrm{~cm}$; sépala dorsal ca. $0,9 \times 0,3 \mathrm{~cm}$, estreito-lanceolada, côncava, ápice agudo; sépalas laterais ca. $0,9 \times 0,2 \mathrm{~cm}$, estreitoelípticas, falciformes, assimétricas, base estreitada, ápice agudo; pétalas ca. $1 \times 0,3 \mathrm{~cm}$, elípticas, ápice agudo; calcar ca. 0,3-0,4 cm compr., claviforme; labelo ca. $0,9 \times 0,9 \mathrm{~cm}, 3$-lobado, dois calos na base; lobos laterais ca. $0,3 \times 0,3 \mathrm{~cm}$, hemielípticos, ápice arredondado; lobo terminal ca. $0,4 \times 0,3 \mathrm{~cm}$, bilobulado; coluna ca. $0,4 \mathrm{~cm}$ compr., polínias 2 . Fruto não observado.

Material examinado: BRASIL. Espírito SAnto: Cachoeiro de Itapemirim, Distrito de Burarama, Barra Alegre, 3-I-2009, A.H. Krahl 167 (VIES); idem, 29-III-2009, A.H. Krahl 183 (VIES).

Oeceoclades maculata está amplamente dispersa por quase todos os Estados do território brasileiro com exceção do Estado do AP (Barros et al. 2013). A população da área de estudo foi encontrada em local sombreado e úmido próximo à base do afloramento rochoso. A floração ocorreu entre os meses de janeiro e março, e a espécie é facilmente reconhecida por possuir folhas de coloração verde clara, maculadas de verde escuro, flores calcaradas e de coloração cremeesverdeada a creme- rosada nas pétalas e sépalas, labelo trilobado alvo com duas máculas rosa e labelo.

18. Pabstiella hians (Lindl.) Luer, Monogr. Syst. Bot. Missouri Bot. Gard. 112: 120. 2007.

Figuras 3 g-i, 5 r

Plantas epífitas, cespitosas. Rizoma inconspícuo. Caule não intumescido em pseudobulbo, cauloma. Cauloma 2,7-9 cm compr., cilíndrico, verde, unifoliado; bainhas 1,6-2,1 cm compr., tubulosas, amplexicaules, ápice agudo. Folhas 6,5-8,1 × 1,6-8 cm, oblanceoladas, levemente coriáceas, ápice verdes, ocasionalmente pintalgadas de roxo, 3-dentado, base atenuada e canaliculada. Inflorescência 14,8-23,5 cm compr., 7-20-flora, laxa, em racemo, floração sucessiva; pedúnculo 8,6-10,8 cm compr., brácteas do pedúnculo 0,4-0,6 cm compr., tubulares, amplectivas; brácteas florais 0,4-0,5 cm compr., amplectivas, ápice agudo. Flores avermelhadas, pintalgadas de vináceo, pediceladas; pedicelo 0,7-1,1 cm compr.; sépala dorsal ca. $0,6 \times 0,3 \mathrm{~cm}$, lanceolada, carnosa no ápice, ápice agudo, base côncava e estreitada; sépalas laterais ca. 0,6 $\times 0,1 \mathrm{~cm}$, linear-lanceoladas, ápice agudo, coalescentes em até $3 / 4$ do seu comprimento; sinsépalo ca. 0,6 $60,2 \mathrm{~cm}$, carnoso em direção ao ápice; pétalas ca. $0,2 \times 0,1 \mathrm{~cm}$, espatuladas, assimétricas, ápice arredondado; labelo ca. $0,2 \times 0,1 \mathrm{~cm}$, triangular a lanceolado, ápice arredondado, base estreita; coluna ca. $0,2 \mathrm{~cm}$ compr., polínias 2 . Fruto não visto.

Material examinado: BRASIL. Espírito SAnTo: Cachoeiro de Itapemirim, Distrito de Burarama, Barra Alegre, 3-I-2009, A.H. Krahl 159(VIES); idem, 29-III-2009, A.H. Krahl 200 (VIES).

Pabstiella hians é endêmica da Mata Atlântica brasileira e foi registrada nos Estados da BA, ES, MG, RJ, SP e PR (Barros et al. 2013). Na área de estudo, a espécie é comumente encontrada em clareiras e apresentou floração entre os meses de janeiro e março. Difere de $P$. trifida por possuir caulomas e folhas maiores, inflorescência com maior número de flores, as quais possuem coloração avermelhada e são pintalgadas de vináceo. Pabstiella hians é reconhecida, dentre as demais espécies, pelas características típicas da subtribo Pleurothalidinae, tais como, porte reduzido, presença de cauloma 
unifoliado, sépalas laterais coalescentes lateralmente, sendo diferenciada dentro da subtribo por ser a maior dentre todas as Pleurothalidinae pela inflorescência longa quando comparada com as demais do grupo, floração sucessiva, flores avermelhadas, pintalgadas de vináceo e pelas sépalas laterais carnosas no ápice.

19. Pabstiella trifida (Lindl.) Luer, Monogr. Syst. Bot. Missouri Bot. Gard. 112: 120. 2007.

Figuras 3 j-1, $5 \mathrm{~s}$

Planta epífita. Rizoma inconspícuo. Caule não intumescido em pseudobulbo, cauloma. Cauloma 1-1,5 cm compr., cilíndrico, unifoliado; bainhas do cauloma 1,1-1,4 cm compr., amplexicaules, ápice agudo. Folha 5,1-5,5 × 0,3-0,5 cm, estreito-elíptica, verde clara, ápice 3-dentado. Inflorescência 2,1-2,5 cm compr., em racemo, floração sucessiva, pauciflora, 1-2-flora; pedúnculo 0,9-1,5 cm compr., brácteas do pedúnculo ca. $0,3 \mathrm{~cm}$ compr., tubulosas, ápice agudo; bráctea floral ca. 0,2 cm compr., lanceolada, amplectiva, ápice agudo. Flores amarelas com listras acastanhadas, pediceladas; pedicelo ca. 0,2 cm compr.; sépala dorsal ca. $0,6 \times 0,3 \mathrm{~cm}$, lanceolada, côncava, ápice agudo; sépalas laterais ca. 0,6 ×0,2 cm, lanceoladas, coalescentes lateralmente até próximo ao ápice, ápice agudo; sinsépalo ca. 0,6 ×0,4 cm, ovado; pétalas ca. $0,4 \times 0,1 \mathrm{~cm}$, espatuladas, assimétricas, levemente falcadas, ápice agudo; labelo ca. $0,4 \times 0,2 \mathrm{~cm}$, triangular a lanceolado, ápice arredondado, base estreitada; coluna ca. $0,3 \mathrm{~cm}$ compr., polínias 2. Fruto não observado.

Material examinado: BRASIL. Espírito Santo: Cachoeiro de Itapemirim, Distrito de Burarama, Barra Alegre, 25-V-2008, A.H. Krahl 59 (VIES).

A inclusão desta espécie no gênero Pabstiella foi proposta recentemente por Luer (2007). Trata-se de uma espécie endêmica da Mata Atlântica brasileira e sua distribuição geográfica foi relatada de forma disjunta entre a região Nordeste e as regiões Sudeste e Sul. Ocorre nos Estados do CE, PB, ES, RJ, SP, PR e SC (Barros et al. 2013). Na área de estudo, os poucos indivíduos de $P$. trifida foram localizados ao longo do curso d'água e o florescimento ocorreu no mês de maio. Difere de $P$. hians por possuir caulomas e folhas menores, inflorescência com menor número de flores, as quais possuem coloração amarela com listras acastanhadas. Dentre as demais ocorrentes na área de estudo, distingue-se pelas características típicas da subtribo Pleurothalidinae, tais como, porte reduzido, presença de cauloma unifoliado, sépalas laterais coalescentes lateralmente, sendo diferenciada dentro da subtribo pela coloração amarela com listras acastanhadas das flores, por possuir no máximo de uma a duas flores abertas simultaneamente e pela inflorescência curta e menor do que o comprimento da folha.

\section{Polystachya sp.}

Planta rupícola. Rizoma inconspícuo. Pseudobulbo 1-1,3 $\times$ 0,6-0,8 cm, fusiforme, verde escuro, 3-foliado. Folhas 7,1-13,4 × 1-1,5 cm, elípticas, conduplicadas, verdes, ápice agudo, base em bainha amplexicaule; bainha foliar 1,5-2 cm compr., recobrindo o pseudobulbo. Inflorescência 13,8-15 cm compr., em panícula, ereta, terminal, 30-37-flora; pedúnculo ca. $8,5 \mathrm{~cm}$ compr.; brácteas do pedúnculo ca. $4 \mathrm{~cm}$ compr., amplectivas ao pedúnculo, ápice agudo; brácteas florais ca. $0,2 \times 0,1 \mathrm{~cm}$, triangulares, ápice agudo. Flores não observadas. Frutos ca. $1 \mathrm{~cm}$ compr., fusiformes, verdes.

Material examinado: BRASIL. Espírito SANTo: Cachoeiro de Itapemirim, Distrito de Burarama, Barra Alegre, 29-III-2009, A.H. Krahl 181 (VIES).

Devido ao fato de ter sido encontrada somente em frutificação, torna-se difícil identificá-la corretamente, no entanto suspeita-se que esta espécie seja $P$. concreta, por ser uma das mais comuns e apresentar registro para a região, ou, ainda, $P$. estrellensis, pelo porte vegetativo. Porém, estas espécies são muitas vezes consideradas por muitos autores como sinônimos. Entretanto, diferem pela morfologia do labelo, uma vez que a tonalidade e o porte vegetativo delas se alteram muito de acordo com o hábitat na qual se encontram (Pabst \& Dungs 1975). Assim, torna-se impossível determinar com precisão a espécie em questão devido à ausência de flores. A espécie foi encontrada vegetando em áreas iluminadas pelo sol pleno sobre rochas ao longo do curso d'água e a frutificação ocorreu no mês de março. Polystachya sp. é reconhecida pelas bainhas recobrindo o pseudobulbo fusiforme e pela inflorescência em panícula que sustenta cerca de 30 flores, neste caso, frutos.

\section{Prescottia plantaginifolia Lindl. ex Hook., Exotic}

flora 2: t. 115. 1824.

Figuras 3 m, n, 5 t

Plantas terrícolas ou rupícolas, heliófilas. Raízes tuberosas. Caule não intumescido em pseudobulbo, 
reduzido. Folhas 11,1-22,7 × 2,9-4,3 cm, rosuladas, lanceoladas, verde claras, pálidas, ápice agudo. Inflorescência 56,8-59,6 cm, terminal, ereta, em racemo congesto, 100-130-flora, floração sucessiva; brácteas florais $0,3-0,5 \mathrm{~cm}$, lanceoladas, ápice agudo. Flores verdes quando jovens e amareladas a acastanhadas à medida que o tempo passa, sésseis, congestas; sépala dorsal ca. $0,3 \times 0,15 \mathrm{~cm}$, lanceolada, ápice agudo; sépalas laterais ca. $0,25 \times 0,2 \mathrm{~cm}$, lanceoladas, ápice agudo; pétalas ca. $0,3 \times 0,04 \mathrm{~cm}$, lineares, ápice retuso ou emarginado; labelo ca. $0,35 \times 0,25 \mathrm{~cm}$, inteiro, cuculado; coluna ca. $0,2 \mathrm{~cm}$ compr., polínias 4 . Fruto verde, ca. $0,7 \mathrm{~cm}$ compr.

Material examinado: BRASIL. Espírito SAnto: Cachoeiro de Itapemirim, Distrito de Burarama, Barra Alegre, 10-VIII-2008, A.H. Krahl 94 (VIES); idem, ibidem, A.H. Krahl 100 (VIES).

Prescottia plantaginifolia possui ampla distribuição no Brasil e ocorre principalmente nos Estados da PB, PE, AL, SE, BA, GO, ES, MG, RJ, SP, PR e SC (Barros et al. 2013). Na área de estudo, os exemplares identificados encontravam-se em locais que recebem incidência solar diretamente nos afloramentos rochosos e podem ser também encontradas em locais abertos nas bordas da mata. A floração e a frutificação foram observadas nos meses de agosto e setembro. A espécie é reconhecida por não possuir pseudobulbo, folhas formando rosetas, inflorescência sustentando aproximadamente 100 flores que possuem o labelo inteiro e cuculado, além das flores não serem ressupinadas.

22. Specklinia marginalis (Rchb. f.) F. Barros, Hoehnea 10: 110. 1984.

Figuras $4 \mathrm{a}, \mathrm{b}, 5 \mathrm{u}$

Plantas epífitas e cespitosas. Rizoma inconspícuo. Caule não intumescido em pseudobulbo, cauloma. Cauloma 0,4-0,6 cm compr., cilíndrico, ereto, unifoliado; bainhas do cauloma 0,3-0,5 cm compr., amplexicaules. Folhas 1,3-2,7 × 0,5-0,6 cm, crassas, oblanceoladas, esverdeada à pintalgada ou completamente arroxeada, base atenuada e canaliculada, ápice 3-dentado. Inflorescência 5,6-7,4 cm compr., em racemo, 7-9-flora, floração simultânea; pedúnculo 2-3,3 cm compr.; brácteas do pedúnculo $0,1 \mathrm{~cm}$ compr., tubulosas, amplectivas; brácteas florais ca. $0,2 \times 0,1 \mathrm{~cm}$, rômbicas, amplectivas. Flores de coloração creme-esverdeada, leve pigmentação arroxeada no labelo, pediceladas; pedicelo ca. $0,2 \mathrm{~cm}$; sépala dorsal ca. $0,3 \times 0,15 \mathrm{~cm}$, lanceolada, côncava, ápice agudo; sépalas laterais ca. 0,35 $\times 0,1 \mathrm{~cm}$, lanceoladas, coalescentes lateralmente até próximo o ápice formando um sinsépalo com ca. $0,35 \times 0,2 \mathrm{~cm}$, oval; pétalas ca. $0,15 \times 0,05 \mathrm{~cm}$, espatuladas, ápice agudo; labelo ca. $0,15 \times 0,05 \mathrm{~cm}$, inteiro, oblongo, ápice arredondado; coluna ca. 0,15 cm compr., polínias 2. Fruto não observado.

Material examinado: BRASIL. Espírito SAnto: Cachoeiro de Itapemirim, Distrito de Burarama, Barra Alegre, 12-X-2008, A.H. Krahl 125 (VIES).

Specklinia marginalis foi transferida para o presente gênero por Barros (1983) e possui afinidade com $S$. grobyi, com a possibilidade de serem confundidas vegetativamente. Entretanto, S. marginalis possui porte vegetativo menor e geralmente não possui listras vináceas longitudinais nas sépalas, as quais podem ser evidenciadas em S. grobyi (Barros 1983). A distribuição geográfica de S. marginalis acontece de forma disjunta entre a região Norte e o Sudeste e Sul. A ocorrência foi descrita nos Estados do PA, MG, RJ, SP, PR, SC e RS (Barros et al. 2013), sendo este o primeiro registro para o Estado do ES. É frequente ao longo do curso d'água da área de estudo, com a floração entre os meses de outubro e novembro. Specklinia marginalis pode ser caracterizada pelas características típicas da subtribo Pleurothalidinae, tais como, porte reduzido, presença de cauloma unifoliado, sépalas laterais coalescentes lateralmente, sendo diferenciada dentro da subtribo pela inflorescência nutante, flores creme-esverdeadas e pelo labelo inteiro e oblongo.

23. Stanhopea guttulata Lindl., Edwards's Bot. Reg. 29 (Misc.): 75. 1843.

Figuras $4 \mathrm{c}, 5 \mathrm{v}$

Planta epífita. Rizoma inconspícuo. Pseudobulbo 3,5-3,8 $\times 1,4-1,8 \mathrm{~cm}$, oval, sulcado, unifoliado, verde. Folha 49,1-49,7 × 6,7-7,5 cm, oblanceolada, subcoriácea, plicadas, verde, ápice agudo. Inflorescência 2-3-flora, direcionada para baixo a partir da base do pseudobulbo; brácteas florais ca. 4,1 $\times 2 \mathrm{~cm}$, lanceoladas, acastanhadas, ápice agudo. Flores grandes de cor alva a creme, pintalgada de vermelho acastanhado, com maior concentração de pontuações no ápice do labelo; sépala dorsal ca. $7 \times 3,2 \mathrm{~cm}$, lanceolada, ápice agudo; sépalas laterais ca. $6,2 \times 3,9 \mathrm{~cm}$, ovadas, convexa, ápice agudo; pétalas ca. $6,1 \times 2,3 \mathrm{~cm}$, lanceoladas, ápice agudo; labelo 
ca. $7 \times 3,4 \mathrm{~cm}$, hipoquílio saquiforme, subquadrado; mesoquílio composto por cornos falcados, quase tão longos quanto o epiquílio; epiquílio ovado, ápice agudo; coluna ca. $6,1 \times 1,6 \mathrm{~cm}$, ápice alado, polínias não vistas. Fruto não observado.

Material examinado: BRASIL. Espírito SAnto: Cachoeiro de Itapemirim, Distrito de Burarama, Barra Alegre, 22-II-2009, A.H. Krahl 174 (VIES).

Stanhopea guttulata possui distribuição restrita à Mata Atlântica dos Estados de MG e RJ (Barros et al. 2013), sendo este o primeiro registro da espécie para o Estado do ES. Na área de estudo, a espécie foi encontrada em árvores adjacentes ao curso d'água, com a floração observada no mês de fevereiro. Stanhopea guttulata é reconhecida, dentre as demais da área, por apresentar a maior flor de todas, com coloração alva a creme, pintalgada de vermelho-acastanhado, hipoquílio saquiforme, subquadrado, mesoquílio composto por cornos falcados, epiquílio ovado e por possuir uma longa coluna alada apicalmente.

24. Stelis papaquerensis Rchb. f., Linnaea 22: 822. 1849.

Figuras 4 d, e, 5 x

Planta epífita, cespitosa. Rizoma inconspícuo. Caule não intumescido em pseudobulbo, cauloma. Cauloma 4,7-5,5 cm compr., cilíndrico, recoberto por bainhas; bainhas do cauloma 2,5-2,9 cm compr., tubulosa, amplexicaules, ápice agudo. Folhas
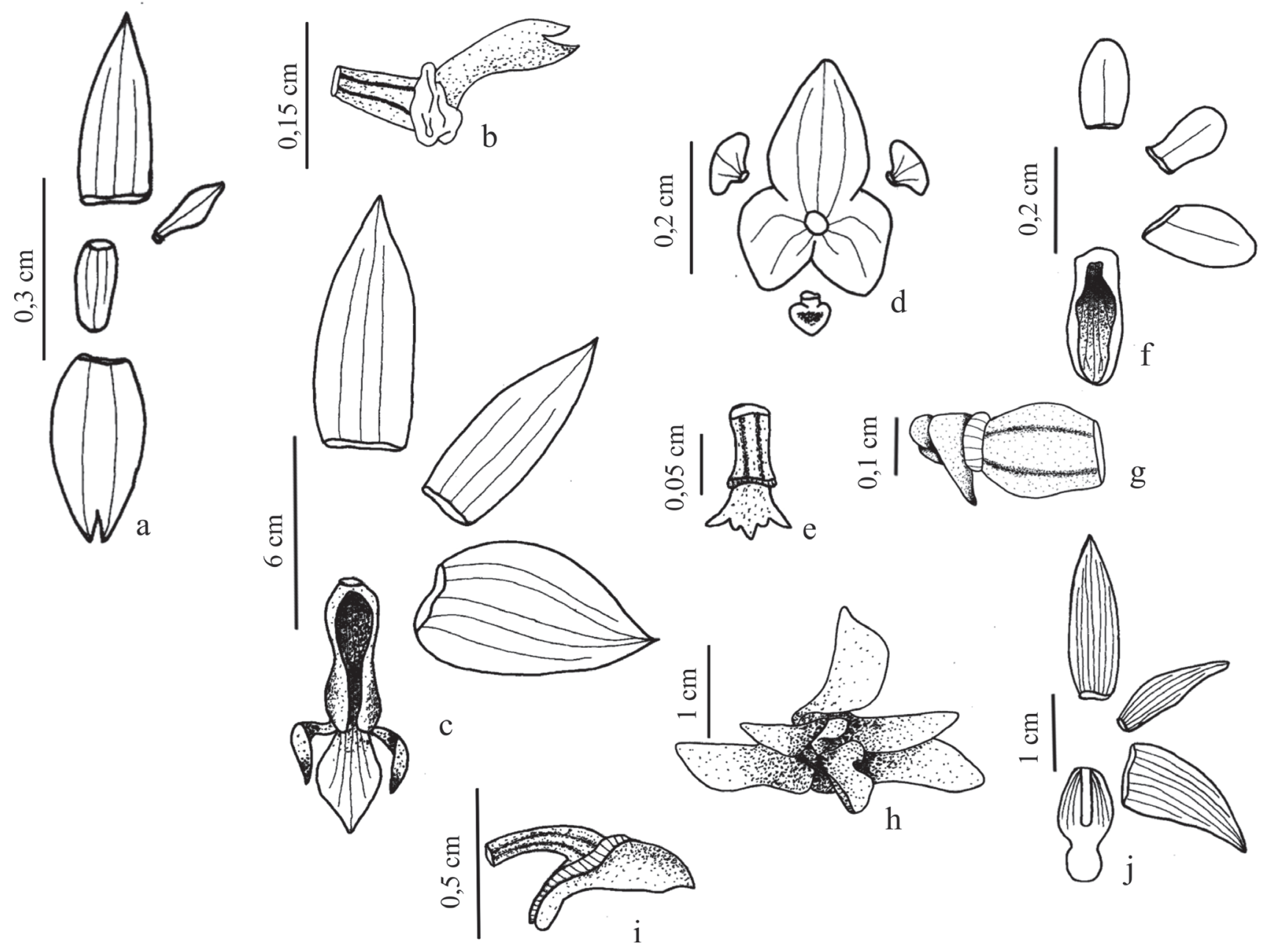

Figura 4. Espécies de Orchidaceae da região sul do Estado do Espírito Santo, Brasil. a-b. Specklinia marginalis. a. Peças florais. b. coluna. c. Stanhopea guttulata. c. Peças florais. d-e. Stelis cf. papaquerensis. d. Peças florais. e. Coluna. f-g. Wullschlaegelia aphylla. f. Peças florais. g. Coluna. h-j. Xylobium variegatum. h. Flor. i. Coluna. j. Peças florais.

Figure 4. Orchidaceae species in the southern Espírito Santo State, Brazil. a-b. Specklinia marginalis. a. Floral parts. b. Column. c. Stanhopea guttulata. c. Floral parts. d-e. Stelis papaquerensis. d. Floral parts. e. Column. f-g. Wullschlaegelia aphylla. f. Floral parts. g. Column. h-j. Xylobium variegatum. h. Flower. i. Column. j. Floral parts. 
6-8,1 × 1-1,4 cm, elípticas, ápice 3-dentado, base atenuada. Inflorescência ca. 16,1 cm compr., ereta, em racemo, 34-58-flora, podendo aparecer duas no mesmo cauloma; espata com ca. $1,1 \mathrm{~cm}$ compr. comprimento, cimbiforme; brácteas florais ca. 0,2 cm compr., infundibulares, amplectivas. Flores de coloração amarela a esverdeada; sépalas coalescentes pela base, pilosas no ápice; a dorsal ca. $0,2 \times 0,15 \mathrm{~cm}$, ovada, ápice arredondado; as laterais ca. $0,15 \times 0,15 \mathrm{~cm}$, ovada, assimétricas, ápice arredondado; pétalas ca. $0,04 \times 0,04 \mathrm{~cm}$, reniformes, ápice arredondado; labelo ca. $0,04 \times 0,04 \mathrm{~cm}$, inteiro, côncavo, semicircular, ápice arredondado, com dois calos arredondados na base; coluna ca. $0,05 \mathrm{~cm}$ compr., polínias 2. Fruto não observado.

Material examinado: BRASIL. Espírito SAnto: Cachoeiro de Itapemirim, Distrito de Burarama, Barra Alegre, 29-III-2009, A.H. Krahl 199 (VIES).

Stelis papaquerensis possui distribuição disjunta entre os Estados do AM, PE, MG, RJ, SP, PR, SC e RS (Barros et al. 2013), sendo este o primeiro registro da espécie para o Estado do ES. No fragmento florestal estudado, exemplares da espécie são frequentes ao longo do curso d'água e desenvolvem-se nos mesmos forófitos que $S$. marginalis. A floração foi observada no mês de março e a espécie pode ser facilmente diferenciada das demais por ser a única encontrada na área que possui as três sépalas coalescentes pela base formando um sinsépalo de formato semelhante a um triângulo.

25. Wullschlaegelia aphylla (Sw.) Rchb. f., Bot. Zeitung 21(16): 131. 1863.

Figuras $4 \mathrm{f}, \mathrm{g}, 5 \mathrm{z}$

Plantas micoheterotróficas, aclorofiladas, áfilas. Caule não intumescido em pseudobulbo, reduzido Inflorescência 17,3-22,5 cm compr., em racemo, ereta, 10-22-flora; pedúnculo 11,5-13,9 cm compr.; brácteas do pedúnculo ca. $0,5 \times 0,1 \mathrm{~cm}$, lanceoladas, ápice acuminado; brácteas florais ca. $0,5 \times 0,1 \mathrm{~cm}$, lanceoladas, ápice acuminado. Flores alvas, pediceladas; pedicelo ca. 0,2 cm compr.; sépala dorsal ca. $0,15 \times 0,1 \mathrm{~cm}$, ovada, côncava, ápice arredondado; sépalas laterais ca. $0,2 \times 0,1 \mathrm{~cm}$, ovadas, ápice arredondado; pétalas ca. $0,15 \times 0,1 \mathrm{~cm}$, ovadas, ápice arredondado, base estreitada; labelo ca. 0,25 ×0,1 cm, elíptico, côncavo, ápice arredondado; coluna ca. $0,1 \mathrm{~cm}$ compr., polínias não vistas. Frutos ca. $0,6 \mathrm{~cm}$ compr., alvos.
Material examinado: BRASIL. EspíRIto SANTo: Cachoeiro de Itapemirim, Distrito de Burarama, Barra Alegre, 3-I-2009, A.H. Krahl 153 (VIES); idem, ibidem, A.H. Krahl 154 (VIES); idem, ibidem, A.H. Krahl 155 (VIES); idem, ibidem, A.H. Krahl 156 (VIES).

Wullschlaegelia aphylla ocorre com distribuição disjunta entre a Amazônia e Mata Atlântica e o Nordeste brasileiro nos Estados de RR, AM, PB, DF, GO, MT, MS, MG, RJ, SP, PR, SC e RS (Barros et al. 2013), sendo este o primeiro registro da espécie para o Estado do ES, o que denota a importância de trabalhos florísticos no Estado. Os exemplares foram encontrados em locais sombreados no interior da mata, só sendo notados durante a sua floração, por se tratar de uma planta áfila. A floração e a frutificação ocorrem no mês de janeiro de forma simultânea. A espécie é distinguida das demais espécies da área por ser áfila e aclorofilada.

26. Xylobium variegatum (Ruiz \& Pav.) Garay \& Dunst., Venez. Orchid. Ill. 2: 342. 1961. Figuras 4 h-j, $5 \mathrm{w}$

Plantas epífitas ou rupícolas. Rizoma 0,8-1 cm compr. entre os pseudobulbos. Pseudobulbos $4,9-8,8 \times 2-2,2 \mathrm{~cm}$, ovais a fusiformes, sulcados, 2 -foliados, verde-escuros. Folhas 47,8-51,2 ×4-6,2 cm, estreito-elípticas, plicadas, verde escuras, pecioladas, ápice agudo, base atenuada e canaliculada; pecíolo 8,3-9 cm compr. Inflorescência 9,5-10,5 cm compr., em racemo, lateral, 10-14-flora; pedúnculo 4,4-5,1 cm compr.; brácteas do pedúnculo ca. 2,9 × 1,7 cm, lanceoladas, amplectivas, castanho-escuras, ápice agudo; bráctea floral ca. $2 \times 0,3 \mathrm{~cm}$, estreitoelíptica a linear, ápice agudo. Flores creme com leves listras róseas e labelo com o ápice vináceo, pediceladas; pedicelo 1-1,2 cm compr.; sépala dorsal ca. $1,5 \times 0,7 \mathrm{~cm}$, lanceolada, ápice agudo; sépalas laterais ca. 1,6 $\times 0,8 \mathrm{~cm}$, lanceolada, ligeiramente falcada, ápice agudo; pétalas ca. 1,4 × 0,4 cm, lanceolada, assimétrica, ápice agudo; labelo ca. 1,3 × 0,6 cm, 3-lobado, disco com um calo longitudinal; lobos laterais ca. $0,7 \times 0,2 \mathrm{~cm}$, hemielípticos; lobo terminal ca. 0,4 cm diâm., orbicular, verrucoso, base estreita, ápice arredondado; coluna ca. 0,6 cm compr., polínias 4. Fruto não observado.

Material examinado: BRASIL. Espírito SAnto: Cachoeiro de Itapemirim, Distrito de Burarama, Barra Alegre, 12-VII-2008, A.H. Krahl 88 (VIES). 

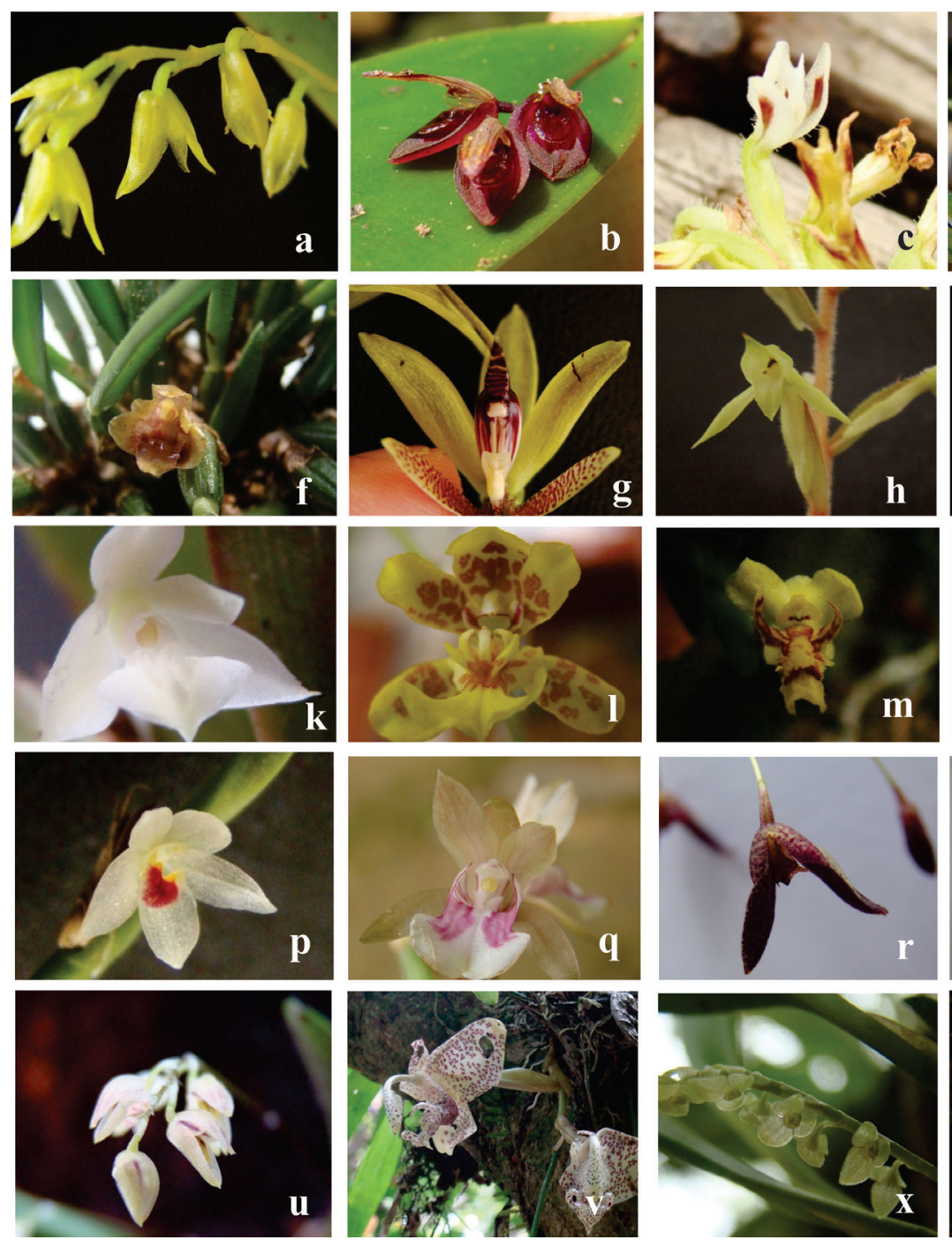
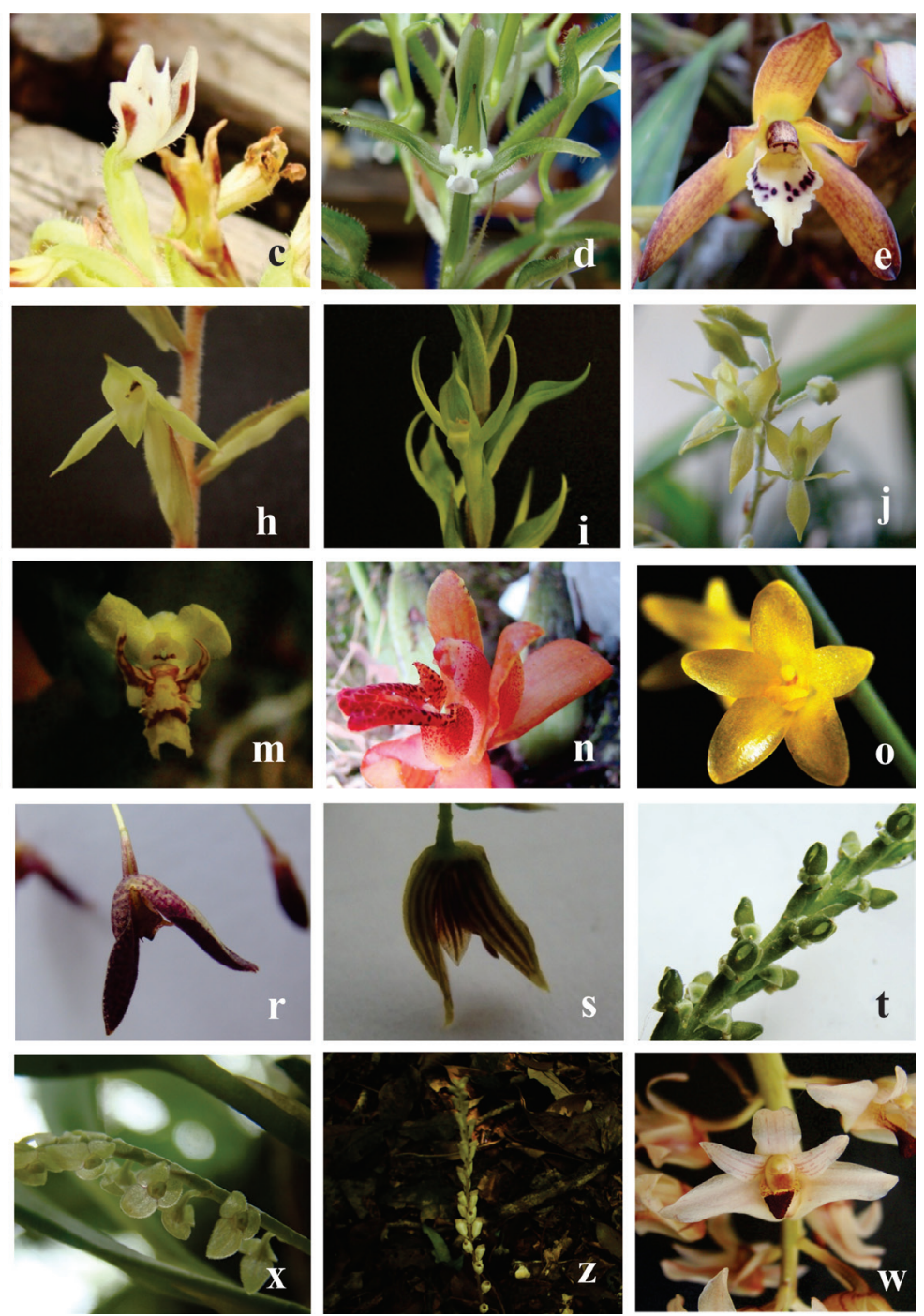

Figura 5. Espécies de Orchidaceae da região sul do Estado do Espírito Santo, Brasil. a. Acianthera capillaris. b. Acianthera nemorosa. c. Aspidogyne argentea. d. Aspidogyne mendoncae. e. Brasiliorchis consanguinea. f. Christensonella pumila. g. Cirrhaea dependens. h. Eltroplectris janeirensis. i. Eltroplectris triloba. j. Epidendrum avicula. k. Epidendrum hololeucum. 1. Grandiphyllum auricula. m. Lockhartia lunifera. n. Mormolyca rufescens. o. Octomeria juncifolia. p. Octomeria tricolor. q. Oeceoclades maculata. r. Pabstiella hians. s. Pabstiella trifida. t. Prescottia plantaginifolia. u. Specklinia marginalis. v. Stanhopea guttulata. x. Stelis papaquerensis. z. Wullschlaegelia aphylla. w. Xylobium variegatum.

Figure 5. Orchidaceae species in the southern Espírito Santo State, Brazil. a. Acianthera capillaris. b. Acianthera nemorosa. c. Aspidogyne argentea. d. Aspidogyne mendoncae. e. Brasiliorchis consanguinea. f. Christensonella pumila. g. Cirrhaea dependens. h. Eltroplectris janeirensis. i. Eltroplectris triloba. j. Epidendrum avicula. k. Epidendrum hololeucum. 1. Grandiphyllum auricula. m. Lockhartia lunifera. n. Mormolyca rufescens. o. Octomeria juncifolia. p. Octomeria tricolor. q. Oeceoclades maculata. r. Pabstiella hians. s. Pabstiella trifida. t. Prescottia plantaginifolia. u. Specklinia marginalis. v. Stanhopea guttulata. x. Stelis papaquerensis. z. Wullschlaegelia aphylla. w. Xylobium variegatum.

Xylobium variegatum possui ampla distribuição geográfica e ocorre de forma disjunta, tendo registro nos Estados de RR, AP, PA, RO, MT, RJ, SP, PR e SC (Barros et al. 2013). Por meio de material depositado no herbário MBML se pode constatar a sua ocorrência para o Estado do ES. Os indivíduos da espécie são relativamente comuns em rochas e árvores ao longo do curso d'água principal que corta o fragmento estudado e floresceram nos meses de julho e agosto. A espécie é reconhecida pela presença de folhas plicadas, pseudobulbo sulcado, labelo trilobado, sendo o lobo terminal orbicular e verrucoso.

\section{Agradecimentos}

Os autores agradecem às famílias Cogo e Dorighetto, por todo o auxílio dado durante as expedições de campo; ao Dr. Cláudio Nicoletti de Fraga, 
pela ajuda na identificação de algumas espécies; às equipes dos herbários MBML e VIES, e à Universidade Vila Velha, pela estrutura física oferecida.

\section{Literatura citada}

Abreu, N.L. \& Menini Neto, L. 2010. As subfamílias Vanilloideae e Orchidoideae (Orchidaceae) em um fragmento da Serra da Mantiqueira, Minas Gerais, Brasil. Boletim de Botânica da Universidade de São Paulo 28: 15-33.

Abreu, N.L., Menini Neto, L. \& Konno, T.U.P. 2011. Orchidaceae das Serras Negras e do Funil, Rio Preto, Minas Gerais, e similaridade florística entre formações campestres do Brasil. Acta Botânica Brasílica 25: 5-70.

Assis, A.M. 2007. Diversidade e conservação das florestas de encosta no Espírito Santo. In: L.F.T. Menezes, F.R. Pires \& O.J. Pereira (orgs.). Ecossistemas costeiros do Espírito Santo: conservação e restauração. EDUFES, Vitória, pp. 45-58.

Assis, A.M., Magnago, L.F.S. \& Fernandes, H.Q.B. 2007. Floresta estacional semidecidual de terras baixas, submontana e montana. In: M. Simonelli, \& C.N. Fraga (orgs.). Espécies da Flora Ameaçada de Extinção no Estado do Espírito Santo. Ipema, Vitória, pp. 52-54.

Atwood, J.T. 1986. The size of the Orchidaceae and the systematic distribution of epiphytic orchids. Selbyana 9: 171-186.

Barros, F. 1983. Flora Fanerogâmica da Reserva do Parque Estadual das Fontes do Ipiranga (São Paulo, Brasil.). 198 - Orchidaceae. Hoehnea 10: 74-124.

Barros, F., Vinhos, F., Rodrigues, V.T., Barberena, F.F.V.A. \& Fraga, C.N. 2010. Orchidaceae. In: R.C. Forzza, J.R. Stehmann, M. Nadruz, A. Costa, A.A. Carvalho Júnior, A.L. Peixoto, A.M.T. Walter, C. Bicudo, A.W.N. Moura, D. Zappi, D.P. Costa, E. Lleras, G. Martinelli, H.C. Lima, J. Prado, J.F.A. Baumgratz, J.R. Pirani, L.S. Sylvestre, L.C. Maia, L.G. Lohman, L. Paganucci, M.V.S. Alves, M. Silveira, M.C.H. Mamede, M.N.C. Bastos, M.P. Morim, M.R. Barbosa, M. Menezes, M. Hopkins, P.H.L. Evangelista, R. Goldenberg, R. Secco, R.S. Rodrigues, T. Cavalcanti \& V.C. Souza (orgs.). Lista de Espécies da Flora do Brasil. Jardim Botânico do Rio de Janeiro, Rio de Janeiro. http://floradobrasil.jbrj.gov.br/2010/FB000179 (acesso em 04.IX.2013).

Barros, F., Vinhos, F., Rodrigues, V.T., Barberena, F.F.V.A., Fraga, C.N., Pessoa, E.M., Foster, W. \& Menini Neto, L. 2013. Orchidaceae. In: R.C. Forzza, J.R. Stehmann, M. Nadruz, A. Costa, A.A. Carvalho Júnior, A.L. Peixoto, A.M.T. Walter, C. Bicudo, A.W.N. Moura, D. Zappi, D.P. Costa, E. Lleras, G. Martinelli, H.C. Lima, J. Prado, J.F.A. Baumgratz, J.R. Pirani, L.S. Sylvestre, L.C. Maia, L.G. Lohman, L. Paganucci, M.V.S. Alves, M. Silveira, M.C.H. Mamede, M.N.C. Bastos, M.P. Morim, M.R. Barbosa, M. Menezes, M. Hopkins, P.H.L. Evangelista, R. Goldenberg, R. Secco, R.S. Rodrigues, T. Cavalcanti \& V.C. Souza (orgs.). Lista de espécies da flora do Brasil. http://floradobrasil.jbrj.gov.br (acesso em 04.IX.2013).
Bastos, C.A. \& van den Berg, C. 2012. A família Orchidaceae no município de Morro do Chapéu, Bahia, Brasil. Rodriguésia 63: 883-927.

Batista, J.A.N. \& Bianchetti, L.B. 2003. Lista atualizada das Orchidaceae do Distrito Federal. Acta Botanica Brasilica 17: 183-201.

Batista, J.A.N., Bianchetti, L.B. \& Pellizzarro, K.F. 2005. Orchidaceae da Reserva Biológica do Guará, DF, Brasil. Acta Botanica Brasilica 19: 221-232.

Bentham, G. 1881. Notes on Orchideae. Journal of the Linnean Society Botany 18: 281-360.

Blanco, M.A., Carnevali, G., Whitten, W.M., Singer, R.B., Koehler, S., Willians, N.H., Ojeda, I., Neubig, K.M. \& Endara, L. 2007. Generic Realignments in Maxillariinae (Orchidaceae). Lankesteriana 7: 515-527.

Buzatto, C.R., Freitas, E.M., Silva, A.P.M. \& Lima, L.F.P. 2007. Levantamento florístico da Orchidaceae ocorrentes na Fazendo São Maximiano, Município de Guaíba, Rio Grande do Sul. Revista Brasileira de Biociências 5: 1-25.

Chiron, G. 2013. Contribution à l'inventaire de la flore d'Orchidaceae d'Espírito Santo (Brésil). Richardiana 13: 198-207.

Chiron, G. \& Bolsanello, R.X. 2013. Orchidées du Brésil: As orquídeas da Serra do Castelo (Espírito Santo Brasil). v.2. Tropicalia, Turriers.

Cogniaux, A. 1893-1896. Orchidaceae. In: C.F.P. Martius, A.G. Eichler \& I. Urban. (eds.). Flora Brasiliensis. F. Fleischer, Munich, v.3, pars 4, pp. 1-672.

Cogniaux, A. 1898-1902. Orchidaceae. In: C.F.P. Martius, A.G. Eichler \& I. Urban (eds.). Flora Brasiliensis. F. Fleischer, Munich, v.3, pars 5, pp. 1-664.

Cogniaux, A. 1904-1906. Orchidaceae. In: C.F.P. Martius, A.G. Eichler \& I. Urban. (eds.). Flora Brasiliensis. F. Fleischer, Munich, v.3, pars 6, pp. 1-604.

Cunha, M.F.B. \& Forzza, R.C. 2007. Orchidaceae no Parque Natural Municipal da Prainha, RJ, Brasil. Acta Botanica Brasilica 21: 383-400.

Docha Neto, A., Baptista, D.H. \& Campacci, M.A. 2006. Coletânea de Orquídeas Brasileiras 3. Brasil Orquídeas, São Paulo.

Dressler, R.L. 1967. The genera Amblostoma, Lanium and Stenoglossum (Orchidaceae). Brittonia 19: 237-243.

Dressler, R.L. 2005. How many orchid species? Selbyana 26: $155-158$.

Fay, M.F. \& Chase, M.W. 2009. Orchid Biology: from Linnaeus via Darwin to the 21st century. Annals of Botany 104: 359-364.

Ferreira, A.W.C., Lima, M.I.S. \& Pansarin, E.R. 2010. Orchidaceae na região central de São Paulo. Rodriguésia 61: 243-259.

Filgueiras, T.S., Brochado, A.L., Noguerira, P.E. \& Guala, G.F. 1994. Caminhamento - Um método expedito para levantamentos florísticos qualitativos. Cadernos de Geociências 12: 39-43. 
Fraga, C.N. \& Pereira, O.J. 1998. Orchidaceae da comunidade pós-praia das restingas do estado do Espírito Santo. Caderno de Pesquisas da UFES 8: 65-72.

Fraga, C.N. \& Peixoto, A.L. 2004. Florística e Ecologia da Orchidaceae das restingas do estado do Espírito Santo. Rodriguésia 55: 5-20.

Hoehne, F.C. 1940. Orchidaceae. In: F.C. Hoehne (ed.). Flora Brasilica. Secretaria da Agricultura, Indústria e Comércio, São Paulo, v.12, parte 1, pp. 1-254.

Hoehne, F.C. 1942. Orchidaceae. In: F.C. Hoehne (ed.). Flora Brasilica. Secretaria da Agricultura, Indústria e Comércio, São Paulo, v.12, parte 6, pp. 1-218.

Hoehne, F.C. 1945. Orchidaceae. In: F.C. Hoehne (ed.). Flora Brasilica. Secretaria da Agricultura, Indústria e Comércio, São Paulo, v.12, parte 2, pp. 1-389.

Hoehne, F.C. 1949. Icnografia das Orchidaceae do Brasil. Secretaria da Agricultura, São Paulo.

Hoehne, F.C. 1953. Orchidaceae. In: F.C. Hoehne (ed.). Flora Brasilica. Secretaria da Agricultura, Indústria e Comércio, São Paulo, v.12, parte 7, pp. 1-397.

Krahl, A.H., Souza, G.R., Boldrini, R.F., Carneiro, B.M., Duca, C. \& Azevedo Júnior, R.R. 2010. Padrão espacial de Eltroplectris triloba (Lindl.) Pabst (Orchidaceae, Spiranthinae) em uma formação florestal de restinga no Sudeste do Brasil. Orquidário 24: 117-123.

Luer, C. 2007. Icones Pleurothallidinarum, XXIX. A Third Century of Stelis of Ecuador, Systematics of Apoda-Prorepentia, Systematics of miscellaneous small genera, Addenda New genera, species and combinations (Orchidaceae). Monographs in Systematic Botany from the Missouri Botanical Garden 112: 106-121.

Menini Neto, L., Almeida, V.R. \& Forzza, R.C. 2004a. A Família Orchidaceae na Reserva Biológica da Represa do Grama - Descoberto, Minas Gerais, Brasil. Rodiguésia 55: 137-156.

Menini Neto, L., Assis, L.C.S. \& Forza, R.C. 2004b. A família Orchidaceae em um fragmento de floresta estacional semidecidual no município de Barroso, Minas Gerais, Brasil. Lundiana 5: 9-27.

Menini Neto, L, Alves, R.J.V., Barros, F. \& Forzza, R.C. 2007. Orchidaceae do Parque Estadual de Ibitipoca, MG, Brasil. Acta Botanica Brasilica 21: 687-696.

Miller, D. \& Warren, R. 1994. Orchids of the high mountain Atlantic Rain Forest in south-eastern Brazil. Salamandra, Rio de Janeiro.

Mori, S.A., Silva, L.A., Lisboa, G. \& Coradin, L. 1989. Manual de Manejo do Herbário Fanerogâmico. 2 ed. Ceplac, Ilhéus.

Myers, N., Mittermeier, R.A., Mittermeier, C.G., Fonseca, G.A.B. \& Kent, J. 2000. Biodiversity hotspots for conservation priorities. Nature 403: 853-858.
Pabst, G.F.J. \& Dungs, F. 1975. Orchidaceae Brasilienses, v.1. Kurt Schmersow, Hildesheim.

Pabst, G.F.J. \& Dungs, F. 1977. Orchidaceae Brasilienses, v.2. Kurt Schmersow, Hildesheim.

Pansarin, E.R. \& Pansarin, L.M. 2008. A família Orchidaceae na Serra do Japi, São Paulo, Brasil. Rodriguésia 59: 99-111.

Pereira, U.Z. \& Ribeiro, L.F. 2004. Caracterização de comunidades de Orchidaceae em Fragmentos de Floresta Ombrófila Densa Montana, em diferentes estágios de regeneração em Santa Teresa, Espírito Santo, Brasil. Natureza on line 2: 52-60.

Rodrigues, J.B. 1877. Genera et Species Orchidearum Novarum, v.1. Typographia Nacional, Rio de Janeiro.

Rodrigues, J.B. 1882. Genera et Species Orchidearum Novarum, v.2. Typographia Nacional, Rio de Janeiro.

Rodrigues, P.J.F.P. \& Nascimento, M.T. 2006. Fragmentação florestal: breves considerações teóricas sobre efeitos de borda. Rodriguésia 57: 63-74.

Rodrigues, T.M. \& Simonelli, M. 2007. Ecologia e conservação de orquidáceas em uma floresta de restinga em Linhares, Espírito Santo. Boletim do Museu de Biologia Mello Leitão, nova série 21: 47-46.

Rodriguez, D.P., Barros, F., Damasceno Júnior, G.A. \& Bortolotto, I.M. 2009. Levantamento da família Orchidaceae no Morro Santa Cruz, Municípios de Corumbá e Ladário, Mato Grosso do Sul, Brasil. Hoehnea 36: 613-636.

Romanini, R.P. \& Barros, F. 2007. Orchidaceae. In: M.M.R.F. Melo, F. Barros, S.A.C. Chiea, M. Kirizawa, S.J. Jung-Mendaçolli \& M.G.L. Wanderley (orgs.). Flora Fanerogâmica da Ilha do Cardoso. Instituto de Botânica, São Paulo, v.12, pp. 29-275.

Romowicz, A. \& Szlachetko, D.L. 2006. Genera et species Orchidalium 12. Oncidieae. Polish Botanical Journal 51: 43-47.

Ruschi, A. 1986. Orquídeas do Estado do Espírito Santo. Expressão e Cultura, Rio de Janeiro.

Sprunger, S. (ed.). 1996. João Barbosa Rodrigues - Iconographie des orchidées du Brésil, v.1: The illustrations. Friedrich Reinhardt, Basle.

Thiers, B. 2013. Index Herbariorum: A global directory of public herbaria and associated staff. New York Botanical Garden's Virtual Herbarium. http://sweetgum.nybg.org/ ih/ (acesso em 12.I.2013).

Veloso, H.P., Rangel Filho, A.L.R. \& Lima, J.C.A. 1991. Classificação da vegetação brasileira, adaptada a um sistema universal. Instituto Brasileiro de Geografia, Departamento de Recursos Naturais e Estudos Ambientais, Rio de Janeiro. 